A-S[clater]
Jamaica 1910 
HARVARD UNIVERSITY.

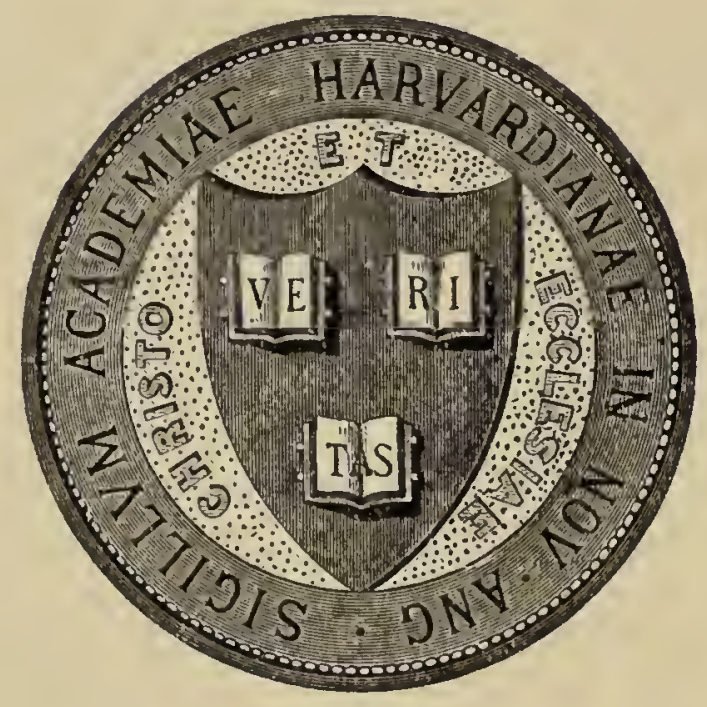

LIBRARY

OF THE

MUSEUM OF COMPARATIVE ZOÖLOGY 52,989 GIFT OF Outram Bangs.

December 17. 1919. 
2.989

\section{REVISED LIST OF THE BIRDS OF JAMAICA}

(Based on the List of Alfred and Edward Newton in the 'Handbook of Jamaica for 1881.')

BY

P. L. SCLATER, Dr. Sc., F.R.S.

Reprinted from the 'Handbook of Jamaica for I9IO.'

KINGSTON, JAMAICA :

THE INSTITUTE OF JAMAICA.

Agents in London, H. Sotheran, \& Co., I40 Strand W.C., and 28 Piccadilly, W. I9I0. 


\title{
THE INSTITUTE OF JAMAICA
}

\author{
FOR THE ENCOURAGEMENT OF LITERATURE, SCIENCE AND ART.
}

Kingston-Temporary Address: 133 Orange Street.

REGULATIONS.

Subscribing Members.-The subscription is five shillings or (to those who wish to borrow additional books) seven shillings and sixpence) per annum payable on election, and on the 1st of April in each following year (or semi-annually at the option of members).

Members Enrolled under Law 3 of 1909. Members of the Kingston Athenæum and other similar institutions are entitled to be admitted as members of the Institute for each current year without subscription on applying to the Secretary and satisfying him that they have paid their subscription to the institution through which they apply.

Members have the right to use the Members Room; to borrow two books (of which one only may be a new book that has been less than six months in the Library) and one magazine from the Library and to attend, and to bring one friend to Members Meetings. Members who pay seven shillings and sixpence a year are entitled to borrow four books (of which two only may be new) and two magazines at a time.

Subscribers to the Library pay two shillings for three months' right to borrow books and magazines on the lines of the five-shillings-a-year membership, or three shillings for the facilities of the seven-shillings-and-sixpence-a-year membership. Unless recommended by a member of the Board, they must lodge a deposit of ten shillings.

Country Members.- - The Government allows free transit by post to and from the Library in the case of books which may be taken to represent reading for the sake of improvement (not novels) and certain periodicals.

Free Departuent.--There is a Free Lending Department, of books not above the value of 10/-each, available for borrowers between the ages of 14 and 19 inclusive, who obtain a guarantor responsible for the books they borrow acceptable to the Board of Governors. One book only may be borrowed at a time.

The Catalogue of the Library, 1895, may be purchased, price 2s., and a Supplement (1909), price 6d. There is a card catalogue in the Library, kept up to date.

Boxes of Books.--Boxes of 100 selected books are lent to local institutions or private individuals, in the country, at a charge of $£ 210 \mathrm{~s}$. (or $£ 15 \mathrm{~s}$. for the older sets) per annum, payable in advance. The boxes are exchanged as often as it is found possible.

The Librairy, Reading-Room, Museum, and Portrait Gallery.-The Library and Reading-Room are open to the public every week-day from $10 \mathrm{a} . \mathrm{m}$. to $5 \mathrm{p} . \mathrm{m}$. on Tuesdays, Thursdays and Fridays: on Mondays, Wednesdays and Saturdays from 10 a.m. till 9 p.m.; the Museum from 10 a.m. to 5 p.m. (shown only to students); the Portrait Gallery is temporarily closed.

Arts and Crafts.-A Competitive and Loan Exhibition of Arts and Crafts is held annually in February. Prospectuses will be supplied on application to the Secretary.

Art Classes.-Art classes are held in connection with the Institute at Wolmer's Girls School. Art Mistress, Mrs. J. A. Allwood (late of the Peterborough School of Art).

CLasses IN Spanish-Classes in Spanish are held in connection with the Institute' at Wolmer's Boys School. Instructor-Mr. E. N Eddowes.

OFFICE Hours. -9 a.m. to 4 p.m.

Forms of application for membership and further particulars may be obtained on application to the Secretary. 


\section{REVISED LIST OF THE BIRDS OF JAMAICA}

(Based on the List of Alfred and Edward Newton in the 'Handbook of Jamaica for 1881.')

BY

P. L. SCLATER, Dr. Sc., F.R S.

Reprinted from the "Handliook of Jamaica for I9TO."

KINGSTON, JAMAICA :

THE INSTITUTE OF JAMAICA.

Agents in London, H. Sotheran, \& Co., I 40 Strand W.C., and 28 Piccadilly, W.

I9IO. 



\title{
REVISED LIST OF THE BIRDS OF JAMAICA.
}

\author{
By P. L. Sclater, Dr. S'c., F.R.S.
}

\section{INTRODUC'TORY REMARKS.}

The principal modern authorities on the ornithology of Jamaica are Gosse (1847) Sclater (1861), March (1863-4), Newton, (1881) and Sicott (1891-3).

Gosse's delightful rolume, published by V'an Voorst in 1847, let in a flood of light upon a subject previously left almost in the dark since the days of Sir Hans Sloane. Cosse was not, strictly speaking, a scientific natmalist, but received valuable assistance from the late (i. R. Gray (and other friends at the British NIuseum), which rendered his excellent field-notes much more valuable. During his eighteen months' stay in Jamaica he resided mainly at Bluefields, a village on the south coastof the Island. In his "Birds of Jamaica" Gosse described about 175 species of birds as met with in the Island.*

Gosse subsequently (1849) planned a volume of 'Illustrations of the Birds of Jamaica,' but did not continue it after' the issue of about 50 plates. References to his "Birds of Jamaica" and his "Illustrations" are quoted in this List as "Gosse" with the page and number of the Plate added to them.

About the beginning of 1858 I made the acquaintance of the late $\mathrm{Mr}$. W. Osburn. who was a friend of Gosse, and had contributed some excellent notes on the Natural History of Jamaica to the 'Zoologist' in 1859 and $1860 . \dagger$

After Mr. Osburn's death in $1861 \mathrm{I}$ was requested by his relatives to undertake the examination of his collection of birds, which I gladly agreed to do. The result was a paper on his collection, which was read before the Zoological Society of London in February 1S61, and was published in their 'Proceedings'. There were 92 species represented in Osborn's series, and amongst them were four examples of a new genus and species of Virconidx, to which I gave the name Laletes osburni in commemoration of the discorerer, besides specimens of 8 species new to the Jamaican Avifauna. The collection also contained a pair of a rare and little known Nightjar (Siphonorhis amoricanus). very remarkable for its elevated tubular nostrils.

A third important paper on the birds of Jamaica drawn up by Mr. W. T. March was communicated by the late Prof. Baird to the Academy of Natural Sciences of Philadelphia in 1863, and was published in that Society's 'Proceedings' for 1863 and 1864. It consisted of a series of field-notes based on the author's own observations, with remarks by Prof. Baird. These are all referred to in the following Revised List.

The next essid in point of date on the Ornithology of Jamaica is the 'List of the Birds of Jamaica' prepared by the brothers Alfred and Edward Nenton, and published in the "Handbook of Jamaica' for 1881, of which the subjoined "Revised List" is in fact a second edition. Like all the work in which Alfred Newton took part this list wis carefully and conscientiously prepared. Well knoming its ralue and correctness. I have only made such alterations in it as were in my opinion absolutely necessary. The original edition has been long out of print, and when I was in Jamaica in 1909 I willingly consented, at the request of Mr. Frank Cundall of the Institue of Jamaica, to prepare a new edition of it. I have, however, made two small additions to it, by stating shortly the 'habitat' and range of every species, and by appending to the List a few remarks on the general character of the Jamaican Avifauna.

Since the publication of the Newtonian 'List' in $18 S 1$ an important addition has been made to our knowledge of the Birds of Jamaica by the excellent field-notes of Mr. W. E. D. Scott who passed the winter of 1890-i in Jamaica. Mr. Scott's 'Obser'rations on the Birds of Jamaicat.' which were published in "The Auk" of 1S91, 1892 and 1893 in a series of eight papers. contain a mass of information on the subject, which should be carcfully studied by those who are interested in Jamaican Ornithology. He gires a complete list of all the birds of the Island known to him (212 in number) and adds excellent remarks on their habits and structure. The

* A riew of the house on the "Bluefields" estate will be found as the frontispiece of Gosse's interesing roiume "A Naturalist's sojourn in Jamaica" published in 1851.

+ See Zoologist, 1850, pp.6355,6587,6658,6709.67+2. and 1860, pp. 6833,6872.6925.

$¥$ See Bull. B. O. C. Vol. xxiii, p. 70. 
"Revised List" subjoined contains exact references to Mr. Scott's "O'servittions," as also to the fou authorities previously mentioned.

I have also supplied in every case a reference to the "Catalogue of Birds in the British II seum," where other" synonyms of the birds will be found.

In conclusion I must not fail to mention that Mr. Charles B. Cory, (formerly of Boston, now of Chicitgoj nas ror many years specially devoted himself to the study of the Birds of the West Indies, and has published the following works which refer to Jamaica as well as to all the other islands of the Greater and Lesser Antilles.

(1) A List of the Birds of the West Indies including the Bahama Islands and the Greater and Lesser Antilles excepting the islands of Tobago and Trinidad. 1 vol. 34 pp. Boston, U S.A., 1885.

(2) A revised edition of the same work. Boston. 1886.

(3) The Birds of the West Indies including all species known to occur in the Bahama Islands, the Greater Antilles the Caymans and the Lesser Antilles excepting the islands of Tobago and Trinidad. By Charles B. Cory, 1 vol., 324pp. Boston, U.S.A. 1889.

(4) Catalogue of West Indian Birds containing a List of all species known to occur in the Bahama Islands, the Greater Antilles, the Caymans and the Lesser Antilles, excepting the islands of Tobago and Trinidad. By Charles B. Cory. Boston, 1892. 1 vol. 4 to. $163 \mathrm{pp}$.

I have given references to Mr. Cory's works when necessary.

\section{LIST OF THE BIRDS OF JAMAICA. \\ FAM. CoRvide.}

Only one member of the Crow-family belongs to the Jamaican Avifauna but other species of this widely spread genus occur in Cuba, Haiti and Porto Rico.

The specimen of Cyanocorax pileatus (referred to by Gosse, p. 208, and by March, p. 360) was in all probability an escaped cage-bird.

1. Corvus jamaicensis Jabbering Crow.

Corvus jamaicensis, Gosse, p. 209, id. Ill. pl. 52: March, Pr. Ac. Phil. 1863 p. 300: Newt. p. 103: Scott, Auk, x. p. 178.

Microcorax jamaicensis, Sharpe, Cat. B. iii. p. 48.

$H a b$. Resident in and peculiar to Jamaica

\section{Fam. ICTERID赵.}

The Troopials-the representatives of our Starlings in the New World, are a numerous group comprising at least 120 species. Of these 6 only are met with in Jamaica, but some of them, such as the Grakle and the Banana-bird, are among the best known species of the Island.

2. Quiscalus Crassirostris. Tinkling Grakle.

Quiscalus crassirostris, Gosse, p. 217; id. Ill. pl. 53: March, Pr. Ac. Ph. 1863, p. 298: Newt. p. 103: Scott, Auk. x. p. 178: Scl. Cat. B. M. xi. p. 398. Hab. Resident, common, peculiar to Jamaica.

3. Nesopsar nigerrimus. All-black Grakle.

Icterus nigerrimus, Osburn, Zool. 1859, p. 457.

Nesopsar nigerrimus, Scl. Ibis, 1859, p. 457: id. P.Z.S. 1861, p. 74: March, p. 299: Newt. p. 103: Scott, Auk, x. p. 278: Scl. Cat. B. xi. p. 353.

$H a b$. Resident, peculial to Jamaica.

4. ICterus vulgaris. Common Troopial

Icterus vulgaris, Cassin, R. Ac. Ph. 1867, p. 46: Newt. p. 104:.

Icterus icterus, Scott, Auk, x. p. 178.

Hab. This is a common cage-bird in South America, probably introduced into Jamaica.

5. Icterus Leucopteryx.

Banana-Bird.

Icterus leucopteryx, Gosse, p. 226: Scl. P.Z.S. 1881, p. 74: March, Pr. Ac. Ph. 1883, p. 299: Newt. p. 104: Sentt, Auk, x. p. 178: Scl. Cat. B. xi. p. 387.

$H a b$. Resident, peculiar to Jamaica

6. Dolichonyx oryzivorus.

Rice-bird.

Dolichonyx oryzivorus, Gosse, p. 229: Scl. P.Z.S. 1861, p. 74: March, Pr. Ac. Ph. 1S63, p. 299: Newt. 1881, p. 104: Scott, Auk, x. p. 178: Scl. Cat. B. xi. p. 331. 
Hab. An abundant migrant from the north, on passage through Jamaica in October and April.

Fam. FRINGILLID A.

The Finches form one of the largest families of Passerine Binds, and are distributed all over the world. In Jamaica they are not abundant, only 7 species being met with, and one of these may have been introduced.

7. Phonipara bicolor. Black-faced Grass-quit.

Spermophilu bicolor. Ciosse, p. 26:2, idl. Ill. pl. 64.

Phonipara marchi, Baird, Pr. Ac. Phil. 186:3, p. 297: Newt. p. 104.

Enctheia bicolor, Scott, Auk, p. 179

Phonipare zene. Baird, Brew and Ridgw. N.A.B. ii. p. 934.

Phonipara bicolor subsp. marchi, sharpe, Cat. B. xii, p. 1.50.

Enethia bicolor marchi, Ridlgw. A.B. i. p. 532.

Hab. Common and resident in Jamaica.

The Jamaican bird has been made different, but it is very lifficult, if possfble to distinguish it from $P$. bicolor.

S. Phomipara omivacea. Jellow-faced Grass-quit.

Spermophilu olivacea, Ciosse, p. 2t9.

Phonipara olivacea, March, Pr. Ac. Ph., 1863, p. 297: Newt. p. 104.

Enetheia olivacer, Scott, Auk, x. p. 179.

Phonipara lepida, Sharpe, Cat. B. xii. p. 145.

Hab. An abundant resident in Jamaica. Spermophila adoxa, Gosse, (p. 253

Ill pl. 65.) seems to be the young of this species.

9. Coturiculus savinaraum. Savamna-bird,

Coturniculus tixicrus, Gosse, p. 2ts, id. Ill. pl. 60.

Coturniculus passerinus, March, Pr. Ac. Ph. 1863. p. 298.

Ammodramus sarannarum, Scott, Auk, x. p. 179: Sharpe, Cat. B. xii. p. 687.

Coturniculus savannarum, Newt. List, 1881, p. 105.

$\mathrm{Hab}$. A north and Central American species, also resident in Jamaica.

10. Pyrrhulagra ruficolis.

Red-necked Coffee-bird.

Pymrhula violacea, Gosse, p. 259, id. Ill. pl. 66:

Loxigilla violacea, Scl. P.Z.S. 1861, p. 74: March, Pr. Ac. Ph. 1863, p. 297:

Newt.p. 104: Scott. Auk, x. p. 180: Sharpe, Cat. B. xii. p. 82.

Pyrrhula robinsoni, Gosse, op. cit. p. 259, id. Ill. pl. 67.

Pyrrhulagra violacea muficallis, Ridgw. B.N.A. i. p. 552.

Hab. Jamaica, resident, represented in the Bahamas, St. Domingo, and other islands by closely allied forms.

11. Pyrrhulagra anoxantha. Yellow-backed Finch.

Spermophila anoxantha, Gosse, p. 247, id. Ill. pl. 62: March, Pr. Ac. Ph. 1863, p. 297: Sclater, P. Z.S. 1861, p. $74:$

Loxigilla anoxantha, Newt. p. 104: Scott, Auk, x. p. 1S0: Sharpe, Cat. B. xii. p. 85.

Loxipasser anoxanthus, Ridgw. B.N.A. i. p 546.

$H a b$. Jamaica, peculiar to the Island.

12. Hedyales ludovichanus.

Lousianan Thick-bill.

Guiraca ludoviciana, Gosse, p. 259: Newt. p. 104.

Habia ludoviciana, Scott, Auk, x. p. 179

Hedymeles ludovicianus, Sharpe, Cat. B. xii. p. 58.

$H a b$. An occasional straggler, from N. America.

13. SyCalis JAMAICE.

Golden-crowned Canary.

Crithagra brasiliensis, Gosse, p. 245, id. Ill. pl. 61.

Sycalis brasiliensis, Scl. P.Z.S. 1861, p. 74.

Sicalis flaveola jamaica, Scott, Auk, x. p. 179.

Sycalis flaveola, subsp. S. jamaico, Sharpe, Cat. B. xii. p. 379.

Hab. Jamaica (Gosse), but said by some authorities to be descended from imported Canaries. It is more likely to be descended from imported specimens of S. brasiliensis, which is a common cage-bird.

\section{Fam. TANAGRID E.}

The Tanagers are also a numerous Family, but are entirely confined to the New World. As many as 360 species are enrolled in the 'Catalogue of Birds.'

Of these only four occur in Jamaica, and one of these four is somewhat doubtful Spindalis is a well-marked genus restricted to the Antilles. Pyrrhuphonice is peculiar to Jamaica. 
14. Pyrrhuphonia jamaica.

Blue Quit.

Euphonia jamaica, Gosse, p. 238, id. Ill. pl. 59.: Scl. P.Z.S. 1861, p. 73: March, Pr. Ac. Ph. 1863, p. 296: Newt. p. 104: Scott, Auk, x. p. 180.

Pyrrhuphonia jamaica, Scl. Cat. B. xi. p. 85.

Hab. A common resident, peculiar to Jamaica.

15. Sindilis vigricephala. Cashew Bird.

Tanagra Zena, Gosse, p. 231, id. Ill. pl. 56:

Spindalis nigricephala. Scl. P.Z.S. 1861, p. 7t: March, Pr. Ac. Ph. 1863, p. 296: Newt. p. 104: Scott, x. p. 1S0: Scl. Cat. B. xi. p. 166: Ridgw. N.A.B. ii. p. 64.

Hab. Resident, peculiar to Jamaica, but with nearly allied representatives in other Islands.

16. Pyranga Ruera. Scarlet Tanager.

Pyranga rubra, Gosse, p. 235: March, Pr. Ac. Ph. 1863, p. 296: Newt. List, 1S\$1, p. 204: Sicl. Cat. B. xi. p. 188.

Piranga erythromelas, Scott, Auk, x. p. 180.

Hab. Apparently only an occasional visitor.

Fam. COEREBIDE.

The Cœrebidre are also a Neotropical Family, of which about 75 species are known. Tro species only are found in Jamaica, and one of these (Glossiptila) is of rather uncertain position.

17. Glossiptila Ruficolilis.

Tanagrella ruficollis, Gosse, p. 236, id. Ill. pl. 58.

Glossiptila ruficollis, Scl. P.Z.S. 1861, p. 73: March, Pr. Ac. Sc., 1S63; p. 296 :

Newt. p. 204: Scott, Auk, x p. 339 Scl. Cat. B. x. 1 p. 48.

Hab. Jamaica, resident in, and peculiar to Jamaica.

18. Certhiola flaveola. Jamaican Sugal-bird.

Certhiola flareola, Gosse, B.J. p. 84, id. I11. pl. 16: Scl. P.Z.S. 1861, p. 73: March, Pr. Ac. Ph. 1863, p. 296: Neivt. List, 1881, p. 105: Scl. Cat. B. si. p. 43.

Careba flaveola, Scott, Auk, x. p. 339.

$H a b$. Resident in Jamaica and peculiar, but with slightly differentiated representatives in other Islands. A single specimen of Coreba cyanea (see Scott. l.s.c.) has been taken in Jamaica, but may have been an escaped cage-bird.

Fam. TURDID $\approx$.

The large and widely spread Family of Thrushes has four representatives in Jamaica. Two of these belong to the typical group of Turdus, the others are members of the purely American subfamily of Mocking-birds (Mimus) which are referred to the Wrens by some authorities, but in my opinion, are better placed in the present family.

19. Turdus Jamicexsis. Glass-eyed Thrush.

Merula jamaicensis Gosse. B.J. p. 142, id. Ill. pl 24: Scott Auk, x. p. 211.

Turdus jamaicensis, Scl P.Z.S. 1861, p. 142: March, Pr. Ac. Ph. 1863 p. 292:

Nent. p. 105: Seebohm, Cat. B.v. p. 208.

Hab. Resident; and peculiar to Jamaica.

20. Turdes aurantius.

Hopping Thrush.

Merula leucogonys, Gosse, p. 136: id. Ill. pl. 23: Turdus aurantius, Scl.

P.Z.S. 1861, p. 70: March, Pr. Ac. Ph. 1883, p. 292.

Semimerula aurantia, Baird, Rev. A. B. p. 34.

Merula aurantia, Scott, Auk, x, p. 342: Seebohm, Cat, B. v. p. 247.

Hab. Resident; peculiar to Jamaica.

21. Mimus orpheus.

Antillean Mocking Bird.

Mimus polyglottus, Gosse, p. 144: Hill .Pr. Ac. Phil. 1863, p. 304.

IT imus orpheus, March, Pr. Ac. Phil. 1853, p. 290: Scl. P.Z.S. 1861, p. 70:

Scott, Auk. x, p. 342: Sharpe, Cat. B. vi. p. 340:

Mimus polyglottos orpheus, Ridgw. B.N.A. iv. p. 231.

Hab. Jamaica and the other Greater Antilles.

22. Mimus hilli. Hill's Mocking-bird. Mimus hilli, March, Pr. Ac. Phil. 1863, p. 291: Scott, Auk, x, p. 341 Sharpe,
Cat. B. vi. p. 34;.

Mimus giendlachi hilli, Ridgw. B.N.A. iv. p. $2 t t$

$H a b$. Peculiar to Jamaica; closely allied to M. gundlachi of Cuba. 
Fam. MNIOTILTID E.

The wood-warblers (Mniotiltidx), which take the place of our sylvians in the New World, form a large and important group, especially prevalent in the Nearctic Region, but mostly going south in Winter. IIr. Ridgway in the third volume of his 'North American Birds' estimated the total number of known species and subspecies of this Family at about 200. Of these about 20 may be placed in the Jamaican List, but nearly all of them are migrants, and pass through the Island on the vernal and autumnal migrations but do not stop to breed.

23. Srurus auricapilues Gold-crowned Water-thrush.

Seiurus auricapillus, Gosse, p. 152:

Henicocichla auricapilla, Scl. P.Z.S. 1S61, p. 70:

Seiurus auricapillus, March, Pr. Ac. Ph. 156:3, p. 294:

Siumes auricapillus Newt. p. 105: Scott. Auk x. p. 341: Sharpe, Cat. Birds x. p. 339: Ridgw. B.N A. ii. p. 635 .

Hab. An occasional winter-visitor to Jamaica from North America.

24. Siurus noveboracenis, New York Water-thrush.

Seiurus noveboracensis, Gosse, p. 151, id. Ill. pl. 2S:

Henicocichla noveboracenis, Sch. P.Z.S. 1S61, p. 70:

Seiurus noveboracenis, March, Pr. Ac. Ph. 1S63, p. 294; Newt. p. 294; Scott. Auk, x. p. 341: Ridgw. B. N.A.ii. p. 642.

Siurus novius, Sharpe, Cat. B. x. p. 343.

$H a b$. A scarce winter-visitor from the north.

25. Siurus MotACILIA,

Siurus motacilla, Newt. p. 105.

Henicocichla motacilla, Scl. P.Z.S., 1861, p. 70.

Sinerus motacilla, Scott, Auk, x. p. 341: Sharpe, Cat. B. x. p. 342: Ridgw. B.N.A. ii. p. 639 .

$H a b$. An occasional visitor in winter from the north.

26. Mniotilta varia.

Black and White Tree-warbler.

Mniotilta varia, Gosse p. 134: Scl. P.Z.S. 1861, p. 76: March, Pr. Ac. Ph.

1863, p. 293: Newt. p. 105: Scott, Auk x. p. 340: Sharpe, Cat. B. x. p.

251: Ridgw B.N.A. ii. p. 432.

$H a b$. A winter visitant from the north, not uncommon.

27. Parula americana.

Blue Yellow-backed Tree warbler.

Parula americana, Gosse p. 154: Scl. P.Z.S. 1861, p 70: March, Pr. Ac. Phil. 1863, p. 298: Newt. p. 105: Sharpe, Cat. B. x. p. 256.

Compsothypis americana, Scott, Auk, x. p. 340 : Ridgw. B.N.A. ii. p. $4 \$ 1$. $H a b$. A regular winter-visitant to Jamaica from the north.

28. Heliinthotherus vermivorus.

Pennsylvanian Swamp-Warbler.

Vermivorus pennsylvanicus, Gosse, B J. p. 150: March, Pr. Ac. Phil. 1863 p. 298.

Helminthotherus vermivorus, Newt. p. 105: Scott. Auk, x. p 340: Sharpe, Cat. B. x. p. 230: Ridgw. B.N.A. x. p. 438.

$H a b$. A regular winter visitant, from the north, but scarce

29. Helondea sivainsoni.

Swainson's Swamp-warbler.

Heloncea Swainsoni, Newton P.Z.S. 1879 p. 552 :

Helminthotherus swainsoni, Newt. p. 105: Sharpe, Cat. B. x. p. 232.

Helinaia swainsoni, Scott, Auk, x. p. 340: Ridgw. B.N.A. x. p. 436.

$H a b$. North America. A rather scarce winter visitant to Jamaica.

30. Dendraca figrina.

Cape-Nay Wood-warbler.

Certhiola maritima, Gosse, p. S7, id. Ill. pl. 17:.

Dendrceca tigrina, Scl. P.Z.S. 1S61, p. 71: March, Pr. Ac. Phil. 1S63, p. 293:

Scott, Auk, x. p. 340: Ridgw. B.N.A. ii. p. 537.

Perissoglossa aigrina, Newt. p 105: Sharpe, Cat. B. x. p. 335.

$\mathrm{Hab}$. A not uncommon winter visitant to Jamaica (Scott)

31. DendR ECA VIRENS,

Black-throated Wood-warbler.

Dendreca virens Newt. P.Z.S. 1S79, p. 522, id. List, p. 106: Scott, Auk, x.

p. 341: Sharpe, Cat. B. x. p. 297: Ridgw. B.N.A. ii. p. 56 ?.

$H a b$. An occasional wintel visitant to Jamaica.

32. Dendraca carulescens

Blue Wood-warbler.

Sylvicola canadensis, Gosse, p. 160

Dendrœca canadensis, Scl. P.Z.S. 1861, p 70: Narch, Pr. Ac. Phil. 1863 p. 293. 
Dendraca carulcscens. Newt. p. 106: Scott, Auk, x. p. 340.

Syluicola pannosa, Gosse, p. 162 id. Ill. pl. 37: Scl. P.Z.S. 1861, p. 71.

Hab. A rither common winter visitant from N. America.

33. DENDRECA CORONATA.

Syluicola coronata, Gosse, B.J. p. 155.

Dendrceca coronata, March. Pr. Ac. Phil, 1863, p. 292: Newt.p. 106: Scott, Auk, x. p. 3 40 : Sharpe, Cat. B. x. p. 313: Ridgw. B.N.A. ii. p.546.

Hab. A winter visitor from North America.

34. Dendrgea pharetra.

Sylvicola pharetra Gosse. p. 163, id. III. p. 3S

Dendroece pharetra, Scel. P. Z.S. 1861, p. 71: Newton, P.Z.S. 1879, p. 552,

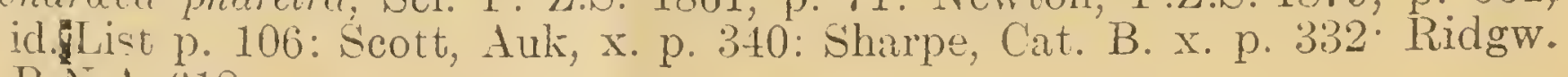
B.N.A.61S.

Hah. Apparently a distinct specie, peculiar to Jamaicat, allied to D. striata (see Newtonl.s.c.)

35. Dendreca striata. Black-poll Warbler.

Dendeca striate Baird, Rev. A.B. p. 192: Newt. P. 106: Scott, Auk, x. p 340: Sharpe, Cat. B. x. p 325: Ridgw. B.N.A. ii p. 595.

Hab. An occasional risitor to Jamaica in winter.

36. Dendreca EOA.

Syluicola eoa, Gosse. p. 158 id. Ill. pl. 34,

Dendreca coa, Baird, R.A.B. p. 195: Nert. p. 106: Scott, Auk, x. p. 340: Sharpe, Cat. B. x. p. 266.

Hab. Dr. Sharpe "has no doubt" (after examining the typical specimens of this form in the British Museum which are the only ones lnown) that this form is a hybrid between $D$. blackburnice and $D$. astiva or $D$. petechia. But Mr. Ridgway (B.N.A. ii. p. 523) does not beliere this to be possible.

37. Dendraci petechia.

Sylvicola cestiva, Gosse, 157.

Red-poll Wood-warbler.

Dendreca petechia, Scl. P.Z.S. 1S61, p. 72: March Pr. Ac. Phil. 1863, p. 92: Newt. p. 106: Scott, Auk. x. p. 340: Sharpe, Cat. B. x. p. 277: Ridgw. B. N. A. ii. p. 515 .

Hab. North America: in Jamaica, a constant resident (Narch)

38. Dendreca palmaruit.

Palm Wood-warbler.

Dendroca palmarmm. Scl. P.Z.S. 1S61, p. 70: Newton, p. 106: Scott, Auk, x. p. 340: Sharpe, Cat. B. x. p. 317 .

Dendreca palmarmm palmarum, Ridgw. B.N.A. ii. p. 612.

Dendreca palmarum hypochrysea, Ridgw. ibid. p. 615.

Hab. A winter visitor to Jamaica, not very common. One individual of the subspecies D. p. hypochrysea was observed by Mr. Scott.

39. Dendraca dominica. Yellow-throated Wood-warbler.

Sylzicola pensilis, Gosse, B.J. p. 156, id. Ill. pl. 32.

Dendroca dominica, Baird, Rev. A.B. p. 209: Newt. p. 106: Scott, Auk, x. p. 340 .

Dendreca superciliosa, March, Pr. Ac. Phil. 1863, p. 293.

Dendreca dominica albilora Scott, Auk, x. p. 340.

Hab. A winter visitant from the north, which may probably occasionally breed. Of 46 specimens procured by Mr. Scott, 22 belong to the subspecies D. d. albitora.

40. DENDRGECA DISCOLOR.

Sylricola discolor, Gosse, B.J. p. 15.

Prairie Wood-warbler.

Dendrocea discolor Sclater, P.Z.S. 1061 p. 71: March, Pr. Ac. Phil. 1863, p. 293: Newt. p. 106: Scott, Auk. x. p. 340: Sharpe, Cat. B. x. p. 307: Ridgw. B.N.A. ii. p. 607 .

Hab. A rather common winter visitor to Jamaica and probably an occasional breeder there.

41 GEOTHLYPIS TRICHAS.

Trichas marylandica, Gosse, p. 148.

Geothlypis trichas, Scl. P.Z.S. 1861 p. 70: March, Pr. Ac Phil. 1863, p. 293 Newt. 166: Scott, Auk, x. p. 341: Sharpe, Cat. B. x. p. 351: Ridgw. B.N.A. x. p. 607.

Hab. A common winter visitant to Jamaica from the north. 
42. WLLonena mitrata.

Hooded Tree-wanther

Myiodinctes mitrutus, Newt. p. 106: Shatpe, Calt. B. x. 4:37

Sylvania mitrata Scott, Auk, X. p. 4:31:

Wilsonia mitrata, Ridgw. B.X.A. ii. p. 705.

Hab. An occasional visitor to Jamaica in winter

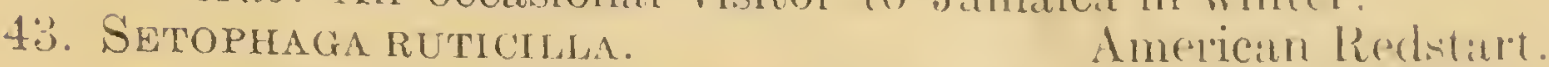

Setophaga ruticilla. Gosse B.J. p 16t: Scl. P.Z.S. Int1, p. 72: March, Pr. Ac. Phil. 1S6:3 p 29:3: Newton, 18s1, p. 106: scott. Auk, x. p. :3+1: Sharpe, Cat. B. x. p. 411 : Ridgw. B.N.A. ii. p. 72t.

Hab. A common winter visitant which may pusibly breed in Iamaica occasionally.

FiMI. VIREONIDA.

The Vireonidit, ol Greenlets, constitute another exchusively American Family of Passerine Birds, being perhaps most nearly allied to the Shrikes Laniidx. In his new work on North and Middle American Birds Dr. Ridgway recognizes about 75 species and subspecies of this family and there are a few more that occur beyond his limits. Only three species of this group have been positively recognized in Jamaica, though it is probable that others may occur there during migration*. One of these three, however, is Laletes osburni a genus and species only found in Jamaica.

44. Vireosylvia calidris.

Jamaican Greenlet.

Vireosylvia altiloque, Scl. P.Z.S. 1861, p. 72: March, Pr. Ac. Phil. 1863. p. 294.

Vireosylvia calidris, Baird, R.A.B. p. 329: Newt. p. 106.

Vireo altiloquus, Scott, Auk, x. p. 339: (Gadow, Cat. B. viii p. 29:3.

Vireosylua calidris calidris, Ridgw. B.N.A. iii. p. 137.

$H a b$. Resident in Jamaica, though in lesser numbers in summer.

45. Vireo MIODESTUS.

Vireo noveboracensis, Gosse, p. 192.

Tireo modestus, Scl.P.Z.S 1860, p. 462: 1861, p. 72, pl. xiv. fig. 1: March, Pr. Ac. Phil. 1863, p. 294: Newt. p. 106: Scott, Auk, x. p. 339: Gadow, Cat. B. vii. p. 303: Ridgw. B.N.A. iii. p. 200.

Hab. Jamaica, resident.

46. LALETES OSBURNi.

Osburn's Greenlet.

Laletes osburni, Scl. P.Z.S. 1861, p. 70, pl. xir. fig. 2; Newt. p. 106; Scott, Auk, x. p. 33:39: Gadow, Cat. B. viii. p. 31:3.

$H a b$. Resident in Jamaica and peculiar to the Istand.

Fam. AMPELID $\mathrm{E}$.

Only one typical member of this family occurs occasionally in Jamaica, but in conformity with the Newtonian arrangement, I leave Iryiadectes here, although I believe it to be more nearly allied to the Turdidx.

47. Ampelis Cedrordir. American Wax-wing.

Ampelis carolinensis, Gosse, B.J. p. 197: March, Pr. Ac. Phil., 1863, p. 294: Newt. List. p. 107: Scott, Auk x. p. 339: Sharpe. Cat. B. x. p. 215: Ridgw. B.N.A. iii. p. 109.

Hab. An occasional visitor from North America in severe winters..

48. Mytadectes solitarius. Solitaire.

Solitcire, Gosse, p. 19ז.

Ptilogonys armillatus, Giray (ien. B1. p. 2s1, pl. Ixix: Sel. P.Zs.' 1861, p. 73: March, Pr. Ac. Ph. 1S6:3, p. 294:

Myiadectes soliterius, Baird, Rer. A.B. p. 421: Newt', p. 107: Scott, Auk. x. p. 341: Sharpe, Cat. B. vi. p. 369. Ridgw. B.N.A. ir. p. 174.

Hab. Highlands of Jamaica, resident, and peculiar to the Island.

$$
\text { Fant. HIRUNDINIDE. }
$$

The widely spread Family of Swallows is represented in Jamaica hy five species one of which is peculiar to the Island. The other four are identical with, or closely allied to North American species.

49. Progne Domnicensis: Antillean Purple-Martin.

Progne dominicensis, Ciosse. p. 69: March. Pr. Ac. Phil. 1963.3. p. 295:

Newt. p. 107: Scott. Auk, x. p. 181: Shanpe, (at. 13. x. p. 176: Ridgw

B.N.A iii. p. 38 .

Hab. Mostly a summer visitor to Jamaica, hut a few remain in winter.

* See March Pr. Ac. Sc. Phil. 1863, 1). 294 
50. Hirundo erythrogastra.

Red-bellied Swallow.

Hirundo erythrogastra, Newt. p. 107: Sharpe, Cat. B. x. p. 137: Ridgw. B.

B.N.A. iii. p. 80 .

Chelidon erythrogaster, Scott, Auk, x. p. 181.

$H a b$. An occasional visitor from North America.

51. Petrochelidon pecilonia.

Antillean Cliff-swallow.

Hirundo pociloma, Gosse, p. 64.

Himundo fulva, March, Pr. Ac. Ph. 1853, p. 295.

Petrochelidon fulva, Scl. P.Z.S. 1861, p. 72: Newt. p. 107: Sharpe, Cat. B. x. p. 195.

Petrochelidon pociloma. Baird, Rev. A.B. p. 292.

Petrochelidon fulta pociloma, Ridgw. B.N.A. iii. p. 54.

$H a b$. Resident, and breeding in the cliffs and in the walls of the towns of Jamaica.

52. Petrochelidon euchirisea Golden Swallow.

Hirundo enchrysea, Ciosse, p. 68, id. Ill. pl. 12.

Petrochelidon euchrysea, scl. P.Z.S. 1861, p. 72.

Hirundo enchrysea, Narch, Pr. Ac. Phil. 1853, p. 295, : Sharpe, Cat. B. x. p. 170 .

Himendo (Callichelidon) euchrysea, Baird, R.A.B. p. 304

Callichelidon euchrysea, Newt. p. 107.

Tachycineta euchrysea, Sentt, Auk, x. p. 181.

Lamprochelidon euchrysea, Ridgw. B.N.A. iii. p. 101.

Hab. Mountains of Jamaica, resident, peculiar to Jamaica.

53. Cotyle riparta. Sand-Martin.

Cotyle riparia, March, Pr. Ac. Phil. 185:3, p. 296: Sharpe, Cat. B. x. p. 96

Clivicola riparia, scott, Auk. x. p. 181.

Riparia riparia, Ridgw. B.N.A. iii. 1). 72.

Hab. North America; an occasional visitor to Jamaica.

Fam. TYRANNID无.

Of the Family Tyrannidx, a large and varied group, absolutely restricted to the New Word, where they probably perform the functions of the Muscicapidæ of the old IVorld, about 550 species have been described. Of these only seven are, as yet, certainly known to occur in Jamaica, and all but one of these seven are peculiar to the Jamaican Avifauna, though some of them are nearly allied and representative forms of species which occur in the other islands of the Antilles.

54. Elainea fallax. Sclater's lily-snapper.

Elainea fallax, Scl. P.Z.S. 1861, p. 76: id. Cat. B. Xiv. p. 147: Newt. p. 107: Scott, Auk, x. p. 17s:

Elcenia fallax, Ridgw. B.N.A. iv. p. 436.

$H a b$. Jamaica, resident, and peculiar to the Island.

55. Myiopagis COTTA.

Cotta Fly-snapper.

Elainea cotta, Gosse, p. 107, id. Ill. pl. 45: .Scl. P.Z.S. 1S61, p. 65: id. Cat. B. xir. p. 149: Narch, Pr. Ac. Ph. 1863, p. 289: Newt. p. 107: Scott, Auk, x. p. 178.

Myiopagis cotta, Ridgw. B.N.A. iv. p. 404.

$H a b$. Resident in and peculiar to Jamaica.

56. Pitangus Jamaicensis.

Common Petchary.

Tyrannus caudifasciatus, Gosse, B.J. p. 177, id. Ill. pl. 44.

Pitangus caudifasciatus, Scl. P.Z.S. 1861, p. 76: March, Pr. Ac. Phil. 1863, p. 28S: Newt. p. 107: Scott, Auk, x p. 17S: Scl. Cat. B. xiv. p. 179, Tolmarchus jamaicensis, Ridgw. B. N. A. iv. p. 682.

Hab. Jamaica, resident and peculiar.

57. Blacicus pallidus.

Buff-winged Flat-bill.

Myiarchus pallidus, Gosse, B.J. p. 266: id. Ill. pl. 40.

Blacicus pallidus, Scl. P.Z.S. 1861, p 77: id. Cat. B. xiv. p. 243.: March, Pr. Ac. Phil. 1863, p. 288: Newt. List, p. 107: Scott, Auk. x. p. 178' Ridgw. B.N.A. iv. p. 5:36.

Hab. Resident: peculiar to Jamaica.

5S. MYiarchus STOLIDUS.

Foolish Petchary.

Myiarchus stolidus, Gosse, B.J. p. 168: id. Ill. pl. 42: Scl. P.Z.S. 1861, p. 77 : id. Cat. B. xiv. p. 260: Narch, Pr. Ac. Phil. 1863, p 288.: Newt. List p. 107: Scott, Auk, x. p. 177: Ridgw. B.N.A. iv. p. 633. 
Hab. Resident in and peculiar to Jamaica.

59. Myiarchús barbirostris.

Myiobius tristis. Ciosse, p. 16, inl. Ill. pl. 41 :

Bearded Petchary.

Blacicus barbirostris, scl. P.Z.S. 1871, p. 85.

Blacicus tristis, March, Pr. Ac. Ph. 1s6:3, p. 290.

Blacicus barbirostris, Newt. List p. 10s: Scott, Auk, x. p. 177: S'cl. Cat. B. xiv. p. 244.

Hab. Jamaica, resident, peculiar.

60. Tyrannus griseús.

Tyranmes dominicensis, Ciosse, B.J. P. 169.

Giray King-bird.

Tyrannus griseus, March, P'r. Ac. Phil. 186:3, p. 287: Newt. List, p. 108

Scott, Auk, x. p. 177: Scl. ('it. B. xiv. p. 271.

$H a b$. Greater Antilles and coasts of America; a summer-visitor to Jamaica.

Fam. COTINGIDA.

The Cotingas (Cotingide) are likewise a very characteristic Family of the Neogean Avifauna. They do not extend so far north and south as the Tyrants but range from Central America to Argentina. The typical forms bear a most gorgeous plumage but only two plain-coloured species occur in Jamaica. One of these belongs to the genus Platypoaris, which has several representatives in South America, but the other (Hylonax) is confined to Jamaica, and has only recently been moved into this Family from the Tyramidx, with which it has been hitherto associated.

61. Platypsaris Niger. Black Beccard.

Tiiyra leuconotus, Gray et Mitch, Gen. B. pl. 63: Gosse; B. J. p. 187.

Puchyrhaimphus niger, Scl. P.Z.S. 1857, p. 72.

Platypsaris niger, Scl. P.Z.S. 1861, p. 77: Ridgw. B.N.A. iv. p. 849.

Hadrostomus niger, March, Pr. Ac. Ph. 1S63, p. 290: Newt. List, p. 108: Scott, Auk, x. p. 177: Scl. Cat. B. xiv. p. 334.

Hab. Highlands of Jamaica, resident, and peculiar.

62. Hylonax validus.

Tyrannus crinitus, Gosse, p. 186. Lusty Wood-King.

Myiarchus validus, Scl. P.Z.S. 1861, p. 76, id. Cat. B. xiv. p. 252.: March, Pr. Ac. Phil. 1863, p. 288: Newt. List, p. 107: Scott, Auk. x. p. 177.

Tyrannula gossii, Bp. Consp. i. p. 189.

Hylonax validus, Ridgw. B.N.A. iv. p. S14.

Hab. Peculiar to Jamaica: Resident.

\section{Fam.TROCHILIDE (Humming-birds.)}

The Trochilidx or Humming-birds of which about 500 species have been described, are entirely confined to the two Americas, and constitute one of the most prominent and peculiar forms of the Neogean Ornis. Only three species of Trochilidæ are met with in Jamaica, and two of these are restricted to that island, while the third is also found in Hispaniola and Porto Rico.

63. LAMPORNIS MANGO.

Mango Humming-bird.

Lampornis mango, Gosse, p. 88, id. Ill. pl. 18: March, Pr. Ac. Phil. i. 1S63: p. 284: Newt. List, p. 108: Scott, Auk, ix. p. 277: Salvin, Cat. B. xvi. p. 91.

Lampornis porphyrura, Scl. P.Z.S. 1S61, p. 79.

Hab. Jamaica, resident, peculiar.

64. Aithurus polyturus. Long-tailed Itumming-bird.

Trochilus polytmus, Gosse, p. 97, id. Ill. pl., 16, 17.

Polytmus cephalater, Scl. P.Z.S. 1861, p. 79.

Aithurus polytmus, March, Pr. Ac. Ph. 186:3, p. 284: Newt. List, p. 108:

Scott, Auk, ix, p. 277: Salvin, Cat. B. xvi. p. 64.

Trocilus maria, Gosse, Ill. pl. 22 (?)

Hab. Jamaica, resident, peculiar.

65. Mellisuga minima.

Vervain Humming-bird.

Mellisuga humilis, Gosse, p. 127, id. Ill. pl. 21.

Mellisuga minima, March, Pr. Ac. Phil. 1863, p. 284: Newt. List, p. 108: Scott, Auk, ix. p. 277: Salvin, Cat. B. xvi. p. 409.

Hab. Jamaica, resident, abundant; also found in Hispaniola and Porto Rico. 


\section{Fam. CYPSELIDE.}

Three of the wide-ranging Fanily of Swifts have been met with in Jamaica. Of these, howerer, only one, the little Palm-swift, is resident, the other two being stragglers from the mainland of America.

66. Crpseluis phenicobius.

Palm Swift.

Tachomis phanicobius. (iosse. p. 58. id. Ill. pl. 9: Newt. p. 108: Hartert, Cat. B. xvi. p. 468.

Cypselus phonicobius, Scl. P'/s.s. 1\$65, p. 604:-March, Pr. Ac. Phil. 1863. p. 287: Scott, Auk, ix. p. 277: Scl. Bull. B. O. C. vol. xxiii, p. 71.

Hab. Jimaica, resident.

67. CrPSELOIDES NIGER.

Black Swift.

Cypselus niger, Gosse, p. 6\%, id. Ill. pl. 10: Narch, Pr. Ac. Ph. 1863, p. 297

C'yrseloides niger, Newt. List, p. 108: Scott, Auk, ix. p. 276: Hart. Cat. B. xri. p. 492

Vephacetes niger, Baird, Rev. A. B. p. 142.

Hab. $\mathrm{N}$. America: an occasional visitor to Jamaica.

68. ChETURA zONARIS.

Collared Swift.

Lenthylis collaris, Gosse, p. 51, id. Ill. pl. 8.

Chatura collaris, Scl. P.Z.S. 1861, p. 79: March, Pr. Ac. Phil. 1863, p. 286.

Acanthyllis collaris, Newt. p. 208.

Hemiprocne zonaris, Scott, Auk, ix. p. 276.

Chatura zonaris, Hartert, Cat. B. xvi. p. 476.

$H a h$. Central and S. America, an occasional visitor to Jamaica.

Fam. CAPRIMUlGID $\approx$ (Nightjars).

The Caprimulgida, or Nightjars, are a well marked and widely distributed group, more abundant in the tropics than elsewhere, and mostly nocturnal in their habits. In Jamaica they have 4 or 5 representatives, one of which (Siphonorhis) is of very peculiar structure, and is restricted to the Island.

69. Nyctibius jamaicensis. Large Potoo.

Nyctibius jamaicensis, Gosse, p. 61, Il. pl. 6.: Scl P.Z.S. 1861, p. 77 : March, Pr. Ac. Phil. 1883, p. 286: Tewt. p. 108: Scott, Auk, ix, p. 275: Hartert Cat. B. xvi. p. 625.

Hab. South and Central America; resident in Jamaica.

70. Nictibicis piluidus. White-headed Potoo.

Nyctibius pallidus, Gosse, p. 69: id. I!l. pl. 7: Sclater, PZ.S. 1S66, p. 129: Scott. Auk, ix. p. 276.

Hab. Jamaica. A rery doubtful species, based by Gosse on a drawing.

71. Chordeidis MiNor.

Chordeiles virginianus, Gosse, p. 33.

Lesser Night-hawk.

Chordeiles popetue, Newt. p. 10 s.

('hordeiles minor, Scl. P.Z.'. 1861, p. 77: March, Pr. Ac. Phil. 1883. p. 286: Nowt. p. 109: Scott, Auk, ix, p. 276: Hartert, C'at. B. xvi. p. 64.

Hab. An occasional visitor to Jamaica in winter.

It seems doubtful whether the larger ('. rirginiomes also occurs in Jamaica. Narch recognized hoth forms.

72. Caprinulgua carolinensis. Clumck-wills-widow

Antrostomus carolinensis, Scl. P.Z.S. 1866. p. 136: Newt. p. 109: Ficott, Auk, ix. p. 276 .

Cayrimulgus carolinensis. Hart. Cat. B. xvi. p. 565 .

Hab. N. America: an occasional visitor to Jamaica in winter.

73. Siphoxorhis americanus. Long-nostrilled Night-jar.

Caprimulgus americanus, Linn. (ex Sloane).

Siphonorhis americanus, scl. P.Z.S. 1861, p. 70: Narch, Pr. Ac. Phil. 1883, p. BA6: Newt. List, p. 109: ścott. Ank, ix. p 276: Hant. Cat. B. xvi. p. 592: Rothsch. Ext. B. p. 4.3 pl. 5, a.

Hab. Jamaica, but very rare and possibly now extinct. Not known else. where.

Fam. (UCLLIDA (Clickos).

The widely spread group of ('uckoos, which number some 175 species, according to the most recent autholities. is represented in Jamaica by five species, one of which, the sole member of its genus, is peculiar to the Island. Another belongs to a genu which is restricted to the Antilles. and is replaced in the adjoining islands by slightly modified forms. 
74. Coccrzus americanus.

Carolina Cuckoo.

Coccyzus americanus, Gosse, B.J. p. 279: Scl. P.Y.S. 1stit, p. 166: Newt.

p. 109: Scott, Auk. ix. p. 27t: Shelley, Cat. B. xix. p. 300.

Coccyzus dominicus, March, ['r. Ac. Phil. 1sfir, p. 154.

Coccyzus bavidi, Scl. P.Y.S. 186t, p. 120.

75. Coccrzus minor.

Milngrore Cuckoo.

Coccyzus minor, Newt. p. 109: Sol P.Z.'. 1866, p. 166: Scott. Ank, ix. p. 274: Shelley, Cat. B. xix. p. :3()t.

Coccyzus seniculus, (iosse, B.J. p. 2S1: Mareh, Pr. Ac. Phil. ISfo., p. 154.

Coccyzus nesiotes, Scl. P.Z.S. 186t. p. 121.

Hab. Central and s'. Anerica. Resident in Jamaica.

76. HYetornis PLuVials.

Rain-bird.

Coccyzus pluvialis, (iosse, p. 277. id. Ill. pl. 7t: March. Pr. Ac. Ph. 186:3, p. 28:3.

Hyetornis pluvialis. Scl. Cat. A.B. p. 321: Newt. List, 1. 109: Scott, Auk, ix. p. 274: Shelley, Cat. B. xix. p. 372.

Hyetomantis pluvialis. Cab. J. F. O. 1862, p $20 \%$.

Hab. Resident in, and peculiar to Jamaicar.

77. SAUROTHERA VETULA.

Mar-bird.

Saurothera vetula, Gosse, B.J. p. 273: Narch, Pr. Ac. Phil 1s6:3, p. 283:

Newt. List, p. 109: Scott, Auk, ix. p. 27:3. Shelley, Cat. B. ixx. p. 370.

Hab. Resident in and peculiar to Jamaica.

78. Crotophiga ani.

Ani.

Crotophaga ani, Gosse, B.J. p. 282: Match, Pr. Ac. Phil. 1863, p. 283: Scl. P. Z.S. 1861, p. 97:

Newt. List, p. 109: Scott, Auk, ix. p. 273: Shelley, Cat. B. xix p. 370.

$\mathrm{Hab}$. South and Central America, extending into the Antilles, a common resident in Jamaica.

Fam. PICID E (Wood-peckers)

Only two Wood-peckers are found in Jamaica. One of then is a member of a genus widely extended in North and South America, while the other is a not uncommon visitor in winter from North America. The paucity of this group in Jamaica is curious, as the Island is very well wooded, and nearly 400 species of Wood-pecker's are known to exist.

79. SPHYRUPICUS VARIUS.

Tellow-bellied Woud-pecker.

Picus varius, Gosse, B.J. p. 270: March, P1. Ac. Sc. Phil. 1863, p. 284.

Sphyropicus varius, Baird, B.N.A. p. 103: Newt. List, 109: Scott, Auk. ix p. 275: Harg. Cat. Birds, xriii. p. 188.

Hab. North America. A not uncommon winter visitant to Jamaica.

80. Centurus radiolatús. Radiolata Wood-pecker.

Centurus radiolatus, Gosse, B. J. p. 271: Scl. P.Z.S. 1861, p.79: March, Pr. Ac. Phil. 1863, p. 284: Newt. List, p. 109: Scott. Auk, ix. p. Harg. Cat. Birds xviii. p. 166.

Hab. Resident in and peculiar to Jamaica.

\section{Fam. ALCEDINIDE (King-fishers).}

The only member of this family in Jamaica ia a well known N. American species. 81. Ceryle alcron. Belted King-fisher.

Ceryle alcyon Gosse, B.J. p. S1: Scl. P'Z.S. 1861: March P'r. Ac. Phil. 1863. p. 284: Newt: List, p. 109: ścott, Auk. ix. p. 274: shanpe. Cat. B. xvii p. 125.

Hab. North Americat. A common wintel visitant to Jamaicat.

Fim. TODIDAS (Todies).

The Todies are one of the most chalricteristic groups of the Antille:m Arifauna, allied to the Motmots on one side and the King-fishers on the other. They are confined exclusively to the four principal islands of the northem group, each of the four (Cubar. Jamaica. Hispaniola* and P'orto Rico) haring its own representative species. 
82. TODUs VIRIDIs. Jamaican Tody.

Todus viridis, Gosse p. 72 id. Ill. pl. 14 Scl. P.Z.S. 1861: Newt. List, p. 109: Scott, Auk, p. 274: Sharpe, Cat. Birds xviii, p. 334.

Hab. Peculiar to Jamaica, but represented by the closely allied species $T$. subulatus, T. multicolor and T. hypochondriacus in Cuba, Hispaniola and Porto Rico.

\section{Fam. PSITTACIDAE (Parrots)}

The Parrots, although much varying in structure, present peculiarities which allow them to be easily distinguished from all other birds so that most Systematists consider them as a separate Order of the Class 'Aves'. The Parrots are very numerous, especially within the tropics of both hemispheres, and more than 500 species have been described.

83. Chrysotis COLlaria.

Psittacus leucocephalus, Gosse, p. 269:

Chrysotis collaria, Scl. P.Z.S. 1861, p. 79: March, Pr. Ac. Phil. 1863, p. 284 Newt. p. 110: Salvad. Cat. Birds, xx. p. 318.

Amazona collaria Scott, Auk, ix. p. 128.

$H a b$. Peculiar to Jamaica, but represented by allied species in the other Islands.

84. Chrysotis Agilis.

Psittacus agilis, Gosse, p. 110:

Chrysotis agilis, Scl. P.Z.S. 1861, p. 69: March, Pr. Ac. Phil. 1883, p. 284: Newt. p. 110.

Amazona agilis Scott, Auk, ix. p. 128.

Hab. Peculiar to Jamaica.

85. Conurus nanus.

Conurus flaviventer, Gosse, B. J. p. 263.

Conurus nanus Scl. P.Z.S. 1861 p. 79: March, Pr. Ac. Phil. p. 284: Newt. p. 110- Scott, Auk, ix. p. 12S, Salvad. Cat. Birds, xx. p. 319.

Hab. Peculiar to Jamaica.

86. Ara gOSSII

Jamaican Macaw.

Ara tricolor? Gosse, B J., p 260: Scott, Auk, ix. p. 129:

Ara gossei, Rothschild, Extinct Birds, p. 56, pl. ii.

$H a b$. Peculiar to Jamaica, but almost, if not quite extinct.

\section{Fam. STRIGID环 (Owls.)}

Only two of the widely diffused groups of Owls, of which some 200 species are known, are met with in Jamaica. One of these is the American form of our Barn-owl, the other is an Eared Owl, so far as is known at present, restricted to the Island.

87. Strix PRATINCOLA.

American Barn-owl.

Strix pratincola, Gosse, B. J., p. 23: March, Pr. Ac. Phil. 1863, p. 153:

Aluco pratincola, Newt. List, p. 111.

Strix flammea furcata, Scott, Auk, 1x. p. 127

Strix flammea, Sharpe, Cat. Birds ii. p. 291.

$H a b$. Widely distributed in America; resident in Jamaica (Gosse).

88. ASIO GRAMMICUS. Lettered Owl.

Ephialtes grammicus, Gosse, B.J. p. 19, pl. 4.

Psendoscops grammicus. Scl. P.Z.S. 1861, p. S0: March, Pr. Ac. Phil, 1863, p. 153: Newt. List, p. 88: Scott, Auk ix p. 117.

Asio grammicus, Sharpe, Cat. Birds ii. p. 242.

Hab. Resident in Jamaica, and, so far as is known, peculiar to the Island.

\section{Fam. PANDIONIDE (Uspreys)}

The sole representative of the ubiquitous Osprey occurs occasionally in $\mathrm{Ja}$ maica.

89. Pandion haliaetus.

Pandron carolinensis Gosse, B.J. p. 19:

Pandion haliaetus, Newt. List, p. 109:

Pandion haliaetus carolinensis, Scott, Auk, ix. p. 127: Sharpe, Cat. B. i.p 449

$H a b$. Coasts of Jamaica, not very common. 


\section{FALCONIDE (Falcons)}

Although more numerous than the Owls the Diurnal Birds of Prey are by no means abundant in Jamaica. Of some 400 species of Falconidx now recognized only five have been met with in the island. Four of these are North American Birds, two of which are permanently resident and breeders. The fifth is a straggler from the mainland.

90. Falco peregrinus Peregrine Falcon.

Falco anatum, Gosse, B.J. p. 16.

Falco peregrinus, Newt. List, p. 110.

Falco peregrinus anatum Scott, Auk, ix. p. 127.

Falco communis, Sharpe, Cat. B. i. p. 376.

Hab. Widely distributed in America, a pair beng found occasionally on the coast of Jamaica.

91. Falco columbarius. American Merlin.

Falco columbarius, Gosse, B.J. p. 17: Newt. p. 110: Scott, Auk, ix. p. 127: Sharpe, Cat. B. i.p. 408.

Hypotriorchis columbarius, scl. P. Z. S. 1861, March, Pr. Ac. Phl. 1S63, p. 132.

Hab. North America: resident in Jamaica

92. Buteo borealis. Red-tailed Buzzard,

Buteo borealis, Gosse, p. 19, id. Ill. pl. 2: Newt, p. 110: Scott. Auk, ix. p 127: Sharpe, Cat. B. i. p. 188.

Hab. A North American species, found all over Jamaica.

93. URubitinga ANThRACINA.

Morphnus urubitinga, Gosse, p. 19.

Urubitinga arthracina, Scott, no. 11t: Sharpe, Cat. i. p. 216.

Hab. Central and South America: Said to have been observed by Mr. Hill (Ciosse.)

94. Elañoides furcatús.

Swallow-tailed Kite.

Nanclems furcatus. Gosse p. 19: Newt. List, p. 110: March, Pr. Ac. Sc. Phil. 1863, p. 158.

Elanoides furcatus, Scott, Auk. ix. p. 126: Sharpe, Cat. B. i. p. 317.

Hab. A North American species of occasional occurrence in Jamaica.

\section{Fam. CATHARTID $\approx$ Turkey-Buzzards.}

The "American Vultures," as they are commonly called, are so different in material points of structure from the Tultures of the Old World, that they ought not to be called by the same vernacular name. About six (distinct) species of this group are known, of which two occur in Jamaica. The red-headed TurkeyBuzzard is a well-known scavenger, and one of the most abundant birds in the Island.

95. Cathartes altra.

Red-headed Turkey-Buzzard.

Cathartes anra, Gosse, p. 1: March, Pr. Ac. Phil. 1863. p. 151: Newt. p. 112: Scott. Auk, ix. p. 126:

Enops aura, Sharpe. Cat. B. i. p. 25.

Hob. Torth and South America; abundant and breeding in Jamaica.

96. Cathartes atratus.

Black-headed Turkey-Buzzard

Cathartes atratus March, Pr. Ac. Sc. Phil. 1863, p. 151: Newt. List, p. 112:

C'athariste atrata, Scott, Auk, ix p. 126.

Catharistes atratus, Sharpe, Cat. B. i. p. 24

Hab. North and South America, occasionally met with in Jamaica.

\section{Fam. ARDEIDE (Herons).}

The Herons, as regards species, are well represented in the Jamaican Arifauna, though they are not in most cases, individually very plentiful. The twelve species of the Island are all enumerated in the American 'Check-list,' but most of them are casual straggler's in Jamaica.

97. ARdeA Herodias.

(ireat Blue Heron.

Ardea herodias. Ciosse. B.J. p. 346: March. Pr. Ac. Ac. Phil. 1863, p. 63:

Scl. P.Z.S. 1S61, p. \$1: Newt. List, p. 111: Scott, Auk, ix. 1. 9: Sharpe,

Cat. B. xxri., p. 80

Hab. -.. America, 'not uncommon in Jamaica.' 
95. ARdea occidentalis.

Great White Heron.

Ardea occidentalis, March, Pr. Ac. Phil. 186t, p. 63: Newt. p. 111: Scott,

Auk, ix. p. 10: Sharpe, Cat. B. xxvi. p. 84.

Ardea wurdemanni, March, op. cit. p. 6t (?)

Hab. North America, an occasional visitor to Jamaica.

99. Ardea EgRETTA.

Herodius egretta. Scl. P.Z.S. 1861, p. s0: March, Pr. Ac. Ph. 1864, p. 63:

Newt. p. 111: Scott, Auk, xi.p. 10: Sharpe, Cat. B. xxvi. p. 95.

Eyrettu leuce, Osburn, Zool. p. 6,932,

Hab. N. America, an occasional visitor to Jamaica.

100. Ardea andidissima.

Americin Little Egret.

Egrette candidissima, Gosse, p. 336. Scl. P.Z.S. 1861, p. 81: Narch, Pr. Ac.

Ph. 1864, p. 63: Newt. List. p. 111: Scott, Auk, ix. p. 10.

Lencophoyx candidissima, Sharpe, Cat. B. xxvi. p. 174.

Hab. N. America; an occasional visitor to Jamaica in winter.

101. ARDEA RUFA. Reddish Egret

Demiegretta rufa, March, Pr. Ac. Phil. 1864, p. 63.

Ardea rufa, Newt. List, p. 111: Scott, Auk, ix. p. 10.

Dicromanassa rufa, Sharpe, Cat. B. xxvi, p. 106.

Hab. N. America; an occasional visitor to Jamaica.

102. Ardea ludooviciana.

Lousianan Egret.

Egretta rufïcollis, Gosse, p. 338, id. Ill. pl. 93:

Ardea ludoviciana, Newt. List, p. 111: Scott, Auk, ix. p. 10.

Demiegretta ludoviciana, March, Pr. Ac. Phil. Is64, p. 63.

Ardea tricolor ruficollis, Scott, Auk, ix. p. 10:

Dichromanassa rufa, Sharpe, Cat. B. xxvi. p. 106.

Hab. North American; "the commonest Heron in Jamaica," (Taylor).

103. Ardea corrulea.

Little Blue Egret.

Egretta coerulea,, Gosse, p. 337.

Florida corulea, Scl. P.Z.S. 1861, p. 81: March, Pr. Ac. Phil. 1864, p. 62.

Sharpe, Cat. B. xxvi. p. 100.

Ardea corvulea, Newt. p. 111: Scott, Auk, ix. p. 10.

Egretta nivea, Gosse, p. $33+$ (jr.?) id. Ill. pl. 90.

Hab. N. America, common in Jamaica (Scott).

104. Butrorides VIREscens.

Green Gaulin.

Herodias virescens, Gosse, p. 340.

Butorides virescens, March, Pr. Ac. Phil. 186t; p. 64: Newt.List, p. 111:

Sharpe, Cat. B. xxvi. p. 186.

Ardea virescens, Scott, Auk, ix. p. 10.

$\mathrm{Hab}$. N. America; common and resident in Jamaicar

105. Ardetta exilis.

American Little Bitter'n

Ardeola exilis, Gosse, B.J. p. 346:

Ardetta exilis, Scl. P.Z.S. 1861, p. 81: March, Pr. Ac. Phil. 1861, p. 64:

Newt. List, p. 111: Sharpe, Cat. B. xxvi. p. 231.

Botaurus exilis, Scott, Auk. ix. p. 9.

Hab. North America, occasional in Jamaica.

106. Botaurus lentiginosus.

American Bittern.

Botaurus minor, Gosse, p. $3+6$.

Botarus lentiginosus March, Pr. Ac. Ph. 186t, p. 65: Newt. p. 111: Scott, Auk, ix. p. 9: Sharpe, Cat. B. xxvi. p. 259.

$H a b . N$. America; an occasional visitor to Jamaica.

107. Nycticorax gardeni.

American Night-heron.

Nycticorax americanus, Gosse, p. 314.

Nyctiardea gardeni, March, Pr Ac. Phil. 1864, p. 65.

Nycticorax gardeni, Newt. p. 111.

Nycticorax nycticorax navius, Scott, Auk, ix. p. 10.

Nycticorax nycticorax, Sharpe, Cat. B. xxvi. p. 146

Hab. N. America; occasionally found in Jamaica.

108. Nycticorax violaceus.

Yellow-crowned Night-heron.

Nycticorax violaceus, Scl. P.Z.S. 1861, p. 81 March, Pr. Ac. Phil. 1864; p. 65, Newt. p. 111: Scott, Auk, ix. p. 11.

Nyctianassa violacea, Sharpe, Cat. B. xxvi. p. 130.

Hab. Central and South America: "common in the extensive mangrove swamps of Jamaica." (Taylor). 
Fiam. PLATALETIOA. (spoonbills).

One of the small family of Spoon-bills which numbers about 6 species, is the sole representative of this peculiar group in the New World, and occasionally visits Jamaica.

109. Platalea ajaja. Roseate Spounbill.

Platalea ajaja, Ciosse, p. 346: March, Pr. Ac. Phil. 1864, p. 65: Newt. p. 65: Ajaja ajaja, Scott, Auk, ix. p. 9: Sharpe, Cat. B. xxvi. p. 52.

Hab. Central and South America of occisional occurrence in Jamaica.

Fam. IBIDII)A. (Ibises).

The Ibises of which some 30 species are known, are found in the warmer portions of both hemispheres. Two of them occisionally visit Jamaica.

110. Eudocimus rubler. Śarlet Ibis.

Ibis mura, (iosse, p. 346: March, Pr. Ac. Phil. 1864.

Eudocimus ruber, Newt. p. 112: Sharpe, Cat. B. xxvi. p. 41.

Gruara rubra, Scott, Auk, ix p 9.

Hab. Central and South Americi. Of occasional occurrence in Jamaica.

111. Eudocinus albus. White Ibis.

Ibis alba, Gosse, B.J. p. 348: Denny. P.Z.S. 1847, p. 39.

Guara alba, Scott, Auk, ix. p. 9.

Eudocimus albus, Sharpe, Cat. B. xxvi. p. 41.

Hab. Central and South America: of occasional occurrence in Jamaica.

Fam. CICONIIDE (Storks).

The Storks a family of which about 15 specics are known, are singularly few in the New World. Only three are found there, and only one of these is an occasional visitor to Jamaica.

112. Tantalus loculator.

Tantalus loculator, Denny, P.Z.S. 1847, p. 39: Scott, Auk, ix. p. 9: Sharpe, Cat. B. xxvi. p. 321.

$H a b$. Central and South America: of occasional occurrence in Jamaica.

FREGATID更. (Frigate-birds).

Only two species of this peculiar Family are known. One of these is said to be common on the south coast of Jamaica, where it breeds.

113. Fregata AqUila. Greater Frigate-bird.

Fregata aquila, Gosse, p. 422: Scott, Auk, ix. p. 363: Grant, Cat. B. xxvi. p. 143.

Hab. IVidely distributed in the tropical seas. Common on the coasts of Jamaica.

Fam. PHAETHONTID瓜. (Tropic-birds).

The Tropic-birds form a small but very distinct Family of Totipalmate Birds allied to the Pelicans and Cormorants. One species is certainly met with on the coasts of Jamaica, but the occurrence of the second is perhaps a little doubtful. In the Catalogue of Birds six species of this group are recognized, all from the inter-tropical seas.

114. Phaethon athereus. Red-billed Tropic-bird.

Pheton athereus, Gosse, p. 430: Newt. p. 112: Grant, Cat. B. xxvi. p. 457.

$H a b$. A widely distributed oceanic bird: occasionally met with on the coast of Jamaica (Gosse) but perhaps not correctly identified.

115. Phanthon flavirostris. Yellow-billed Tropic-bird.

Phaethon flavirostris Scott, Auk, viii. p. 249, et p. 362.

Phaethon americanus, Grant, Cat. B. xxvi. p. 456.

Hab. American seas: north coast of Jamaica, resident and breeding (Scott).

Fam. SULIDAE. (Gannets).

The Gamnets are another small Family of oceanic birds scattered nearly all over the world. Three species out of the six recognized in the Catalogue of Birds have been recorded as met with on the coasts of Jamaica.

116. Sula leucogastra. Brown Booby.

Sula fusca, Gosse, B.J. p. 417.

Sula leucogaster, Newt. p. 112.

Sula fiber, Gosse, p. 418 (?).

Sula sula, Scot, Auk, ix. p. 363: Grant, Cat. B. xxvi. p. 436.

$H a b$. Coasts of Jamaica (a widely distributed species). 
117. Sula PISCATOR

Black and White Booby.

Sula piscator, Gosse, B.J. p. 418: Newt. p. 112: Scott, Auk, ix. p. 362:

Grant, Cat. B. xxvi.p. 432.

Sula parva, Gosse, l.c. (?).

Hab. Coasts of Jamaica (widely distributed).

118. Sula Cranops. Blue-faced Booby

Sula cyanops, Cory, B. of West Ind. p. 272: Scott, Auk, ix. p. 363: Grant, Cat. B. xivi. p. 430.

Hab. Caribbean sea (a midely distributed species).

\section{Fam. PELECANID $巴$ (Pelicans).}

About eight or nine species of the peculiar Family of Pelicans are known. They frequent the fresh and tidal waters of both hemispheres. One species occurs on the coasts of Jamaica.

119. Pelecanus fuscus. Brown Pelican.

Pelecanus fuscus Gosse, p. 409: Scott, Auk, ix. p. 112: Grant, Cat. B. xxvi. p. 475.

Hab. North and Central America: coasts of Jamaica (Gosse).

Fam. PHCENICOPTERIDE (Flamingoes).

The Flamingoes, a small group of which seven species are known, are found in both hemispheres. The one North American representative of this peculiar Family breeds in the Bahamas, and occurs occasionally in Jamaica.

120. Phœítcopterus ruber. Scarlet Flamingo.

Phonicopterns ruber, Gosse, p. 390: March, Pr. Ac. Phil. 1864, p. 65: Newt.

List, p. 365: Scott, Auk, ix. p. 365: Salvad. Cat. B. xxvii. p.

Hab. North America, occasional in Jamaica.

Fam. ANATID无. (Ducks).

Hore than thirty species of the great Family of Anatidx., lave been recorded as occurring in Jamaica, but the large majority of these only visit the Island in winter; when driven southwards from their homes by the ungenial weather of Arctic America. The only Ducks really resident in Jamaica and regularly breeding there are the two Tree-ducks of the genus Dendrocygna and one of the Pond-ducks (Nomony.r).

121. Chex hyprboreus. Show Goose.

Chen hyperboreus, Gosse, B.J. p. 408: Newt. List, p. 112: Scott, Auk, viii p. 365: Cory, B. W.T. p. 259: Salvad. Cat. B. xxvii. p. 84.

Anser hyperboreus, March, Pr. Ac. Phil. 1864, p. 70.

Hab. N. America, accidental in Jamaica, in winter (Hill).

122. Branta Canadensis. Canada Goose.

Anser canadensis, Gosse, B.J. p. 408: March, Pr. Ac. Phil. 186t, p. 70: Newt. List, p. 112.

Branta cunadensis, Scott, Auk, viii. p. 365: Salvad. Cat. B. xxvii. p. 112.

Hab. N. America: an accidental visitor in winter to Jamaica (Hill).

123. Dendrocicna ARBOREa. Black-billed Whistling Duck.

Dendrocygna urborea, Gosse, B.J. p. 395: March, Pr. Ac. Phil. 186t, p. 10: Newt. p. 112: Scott, Auk. viii. p. 65: Salvad. Cat. B. xxvii p. 162.

Hab. Antilles: resident in Jamaica.

124. Dexprocirena autumalis. Red-billed Whistling Duck.

Dendrocycno autumnalis, Gosse, p. 398: March, Pr. Ac. Ph. 1864, p. 70: Newton, p. 112: Scott. Auk, viii. p. 363: Salvad. Cat. B. xxrii. p. 159.

$H a b$. Central Americi. Resident in Jamaica, but not so common as D. arborea.

125. CAIRINA MUECHATA.

Muscory Duck.

Cairina moschutu, Gosse, B.J. p. 408: March, Pr. Ac. Sc. Phil. 1864, p. 72: Newt. List, p. 112: Salvad. Cat. B. xxvii. p. 51.

Hab. South America: an occasional visitor to Jamaica (Hill).

126. Avas bosciss. Common Wild Duck.

Anas boscrs, (iosse, p. t08: March, Pr. Ac. Ph. 1864, p. 72: Newt. List, p. 113: Scott, Auk, viii. p. 363: Cory, B. of II. I. p. 262: Salrad. Cat. B. xxrii. p. 1 s 9.

Hab. N. Americi, accidental visitor to Jamaica.

Anas maxima (Gosse. B.J., p 408, id. Ill. pl. 110) was probably founded on a hybrid. 
127. Anas obscura.

Dusky Duck.

Anas obscura, Gosse, p. 408: March, Pr. Ac. Sc. Phil. 1864, p. 72: Newt.

p. 113: Scott, Auk, viii. p. 363: Salvad. Cat. Birds, xxvii p. 200.

Hab. North America, occasional in Jamaica.

128. ANAS STREPERA.

Gadwall.

Chaulelasmus streperus, Gosse, p. 408: March, Pr. Ac. Phil. 1864, p. 72:

Anas strepera, Newt. p. 113: Scott, Auk, viii. p. 364: Salvad. Cat. B. xxvii. p. 221.

Hab. North America: a more or less regular visitor to Jamaica in winter

129. Querquedula carolinensis.

Green winged Seal.

Querquedula carolinensis Gosse p. 406: March, Pr. Ac. Phil. 1864, p. 72:

Newt.p. 113.

Anas carolinensis, Scott, Auk, viii. p. 364.

Nettion carolinense, Salvad. Cat. Birds, xxvii. p. 250.

Hab. N. America; a winter-visitor to Jamaica (Gosse).

130. Querquedula discors.

Blue-winged Teal.

Cyanopterus discors, Gosse, p. 401: Scl. P.Z.S. 1861, p. 82: March, Pr. Ac.

Phil. 1S64, p. 71: Newt. p. 113: Salvad. Cat. B. xxvii. p. 299.

Anas discors, Scott, Auk, viii. p. 364.

Cyanopterus inornatus, Gosse, B.J. p. 402, id. Ill. pl. 111.

Querquedula inornata, March, Pr. Ac. Phil. 1864, p. 71: Newt. p. 113.

Hab. North America. Resident in Jamaica (Gosse).

131. DaFila ACUTA.

Pintail.

Dafila acuta, Gosse, p. 408: March, Pr. Ac. Phil. 1864, p. 71: Newt. p. 113: Scott, Auk, viii. p. 364: Salvad. Cat. B. xxvii. p. 270.

$H a b$. Norther'n Hemisphere. A frequent visitor to Jamaica in winter.

132. Dafila Bahamensis.

Bahama Duck.

Pocilonetta bahamensis, Gosse, p. 308: March, Pr. Ac. Phil. 1864, p. 71.

Dafila bahamensis, Newt. p. 113.

Pcecilonetta bahamensis, Salvad. Cat. B. xxvii. p. 282.

$H a b$. North and Central America; occasional in Jamaica.

133. MARECA AMERICANA.

American Widgeon.

Mareca americana, Gosse, p. 408: March, Pr. Ac. Phil. 1864, p. 71: Newt. p. 113: Salvad. Cat. B. xxvii. p. 233.

Anas americana, Scott, Auk, viii. p. 363.

$H a b . \quad$ N. America; an occasional visitor to Jamaica in winter.

134. Spatula clypeata. Shoveler.

Rhynchaspis clypeata, Gosse, p. 408.

Spatula clypeata, Scl. P.Z.S. 1861, p. 82: March, Pr. Ac. Phil. 1864, p. 72:

Newton, List, p. 113: Scott, Auk, viii. p. 364: Salvad. Cat. B. xxvii. p. 306. $\mathrm{Hab}$. Northern Hemisphere: an occasional winter-visitant to Jamaica.

135. Ax SPONSA. Summer-duck.

Aix sponsa Gosse, p. 408: March, Pr. Ac. Ph. 1864, p. 72: Newt. p. 113: Scott, Auk, viii. p. 364:

AE $x$ sponsa, Salvad. Cat. B. xxvii. p. 73.

Hab. North America; a rather scarce winter-visitor to Jamaica.

136. Fuligula affinis.

Fuligula affinis, Gosse p. 408 (Hill).

American Scamp-Duck.

Fulix affinis, March, Pr. Ac. Phil. 1864, p. 71.

Nyroca affinis, Newt. p. 113.

Aythya affinis, Scott, Auk, viii. p. 364.

Fuligula affinis, Salvad. Cat. B. xxvii. p. 360.

Hab. North America. Of occasional occurrence in Jamaica in winter.

137. Fuligula coldaris.

Fuliqula rufitorques, Gosse, p. 408.

Collared Duck.

Fulix collaris, March, Pr. Ac. Phil. 1864, p. 72.

Nyroca collaris, Newt. p. 113.

A ythya collaris, Scott, Auk, viii. p. 364.

Fuligula affinis, Salvad. Cat. Birds xxvii. p. 370 .

$H a b$. North America. Of occasional occurrence in Jamaica in winter. 
138. Fuligula americana.

American Pochard.

Fuligula americana, Ciosse, B. J. p. 40 S.

Aythya americana, Nareh, Pr. Ac. Phil. 1S64, p. 72.: Scott, Auk, riii p. 364

Nyroca americana, Newt. p. 113: Salvad. Cat. B. xxrii. p. 340.

Ilab. North Ameruca. A rather scarce winter risitor to Jamaica.

139. Fuligula ferruginea. White-eyed Duck.

Nyroca leucophthalma, Gosse, B.J., p. 408: March, Pr. Ac. Sc. Phil. 1864, p. 72: Newt. p. 113.

Nyroca africana, Salvad. Cat. Birds, xxvii. p. 345.

Hab. Northern portion of the Old World. There is probably some error about this Duck being in the List of Jamaican Birds, as it does not occur in North America.

140. Fuligula vallisneria. Canvass-backed Duck.

Aythya valisneria, March, Pr. Ac. Phil. 1864, p. 72: Scott, Auk, viii. p. 364. Nyroca valisneria, Newt., p. 113: Salvad. Cat. B. xxvii. p. 342.

Hab. N. America. An occasional winter-visitor to Jamaica.

141. Cipdema perspicilliata.

Surf Scoter.

Edemia perspicillata, Gosse: March, Pr. Ac. Phil. 1864, p. 72: Newt. p. 113: Scott, Auk, viii.p. 364: Salvad. Cat. Birds, xxvii. p. 412.

Hab. North America. Said to have occurred in Jamaica.

142. Nomonyx Dominicus.

Erismatura spinosa, Gosse, p. 404 ..

Spine-tailed Duck.

Erismatura rubida, Newt. p. 113.

Erismatura rubida, Gosse, B. J., p. 406, id. Ill. pl. 113.

Nomonyx dominicus, Scott, Auk, viii. p. 364: Salvad. Cat. Birds, xxvii. p. 438 .

Hab. North America. Resident in Jamaica (Scott).

143. Erismatura Jamaicensis. Ruddy Duck.

Enilismatura rubida, Scott. Auk, viii. p. 364.

Erismatura jamaicensis Salvad. Cat. B. xxvii. p. 445.

$H a b$. Tropical America. Occasionally found in Jamaica.

\section{ORDER COLUMBÆ (Pigeons).}

The large order of Pigeons, which embraces over 400 species, and is most numerous in the tropics, is represented in Jamaica by nine members. Three of these belong to the widely spread genus Columba, the others to genera restricted to the New Worls.

The very remarkable Pigeon Starnonas cyanocephala of (uba, is stated to have been formerly found in Jamaica (cf. Scott, Auk, ix. p. 125), but there seems to be no certain evidence of its recent occurrence.

144. Columba leuococephala. Baldpate Pigeon.

Columba lencocephala, Gosse, p. 99: March, Pr. Ac. Phil. 1863, p. 301: Newt.

p. 114: Scott, Auk, ix. p. 122: Salvad. Cat. Birds, xxi. p. 278.

Patagicenas leucocephala, Scl. P.Z.S. 1S61, p. 80.

$H a b$. Central and South America; a common resident in Jamaica.

145. Columiba Caribera.

Ring-tailed Pigeon.

Columba caribae, Gosse, p. 291: March, Pr. Ac. Phil. 1863, p. 301: Newt. p. 114: Scott, Auk, ix. p. 122: Salvad. Cat. B. xxi.p. 293.

Patagiœnas caribcea, Scl P.Z.S. 1861, p. 80.

$H a b$. A common resident in Jamaica and other Antilles.

146. LOLUMBa inORNATA.

Columba rufina, Gosse, p. 296.

Chlorænas inornata, Scl. P.Z.S. 1S61, p. 80.

Columba inornata, March, Pr. Ac. Phil. 1863, p. 301: Newt. p. 114: Scott, Auk, ix., p. 122: Salvad. Cat. Birds, xxi. p. 284.

$H a b$. Jamaica and the other Greater Antilles.

147. ZFNAIDA AMABILIS.

Pea-dove.

Zenaida amabilis, Gosse, B.J. p. 307 : Scl. P.Z.S. 1861, p. 80, March, Pr. Ac. Phil. 1863, p. 302: Newt. p. 114: Salvad. Cat, B, xxi. p. 382.

Zenaida zenaida, Scott, Auk, ix. p. 123. 
Hab. Jamaica and the other Antilles. 'There appear's to have been some error about the locality of Ciosse's 'Blue Partridge' (13.J. 1). 32-1 Kenaida plumbea, id. Ill. pl. S5), which is a Brazilian species. (cf. Salvad. Cat. B. xxi., p. $379,389$.

148. Melopelia leucoptera

T'urtur leucopterus, Giosse, p. 304:

Zenaida leucoptera, Scl. P.Z.S. 1861, p. 80:

Melopelia leucoptera, Newt. p. 114: March, Pr. Ae. Phil. 1Sti:, p. :302: Scott, Auk, ix. p. 123; Salvad. Cat. Birds, xx. p. 392.

Hab. Central America and Antilles: common and resident in Jinmaica.

149. Chamapelia passerina.

Passerine Ground-dove

Chamapelia passerina, Gosse, B.J. p. 311: March, P'r. Ac. Phil. 1863, p. 302: Scl. P.Z.S. 1861, p. S0: Newt. p. 114: Salvad. Cat. B. xxi. p. 472.

Columbigallina passerina, Scott, Auk, ix. p. 12:3.

Hab. Antilles: a common resident in Jamaica.

150.. LEPTOP'TILA JAMAICENSIS.

White-bellied Dove.

Peristera jamaicensis, Gosse, p. 313.

Leptoptila jamaicensis, March, Pr. Ac. Phil. 1863, p. 302: Salvad. Cat. B xxi. p. 557.

Engyptila jamaicensis, Newt. p. 114: Scott, Auk, ix. p. 123.

$\mathrm{Hab}$. Jamaica; resident and common in some localities: peculiar to Jamaica.

151. Geotrygon cristata. Blue Dove.

Geotrygon sylvatica, Gosse, B. J., p. 316: id. Ill. pl. 84.

Geotrygon cristata March, Pr. Ac. Phil. 1S63, p. 300: Newt. p. 114: Scott, Auk, ix. p. 124: Salvad. Cat. Birds, xxi. p. 573.

$H a b$. Peculiar to Jamaica, said to be becoming extinct since the introduction of the Mongoose.

152. Geotrygon montana.

Partridge Dove.

Geotrygon montana, Gosse, p. 321: March, Pr. Ac. Phil. 1862, p. 300: Newton p. 114: Scott, Auk, ix. p. 125: Salvad. Cat. B. xxi. p. 567.

$H a b$. North and South America; resident in Jamaica.

\section{Fam. RALLID无 (Rails).}

There are five species of Rails found in Jamaica, all of which are likewise met with on the adjoining mainland. The Coot of Jamaica and the two Water hens have a similar distribution. Nearly 200 species of the Ralline Family are known. They are found in nearly every part of the earth's surface, and are remarkable for their wandering habits, though they liave feeble powers of flight.

153. RALlUS CARIBEUS.

Caribee Rail.

Rallus longirostris, Gosse, p. 364: Newt. p. 114.

Rallus crepitans, Scl. P.Z.S. 1S61, p. 81.

Rallus clegans, March, Pr. Ac. Phil. 1864, p. 69.

Rallus longirostris var caribeus, Ridgw. Bull. Nutt. Cl. v. p. 140.

Rallus longirostris subsp. j. R. caribueus, Sharpe, Cat. Birds xxiii. p. 13.

Hab. Jamaica and other Antilles.

154. Porzana carolina.

Ortygometra carolina, Giosse, p. 371:

Pozzana carolina, Scl. P.Z.S. 1S61, p. 81: March, Pr. Ac. Plil. 1864, p. 69:

Newt. p. 114: Scott, Auk, p. 11: Sharpe, Cat. B. xxiii. p. 97.

Hab. North America; Jamaica, commoner in winter.

155. POR' $/$ ANA CONCOLOR.

Red Crake.

Rallus concolor, Gosse, B.J. p. 369, id. Ill. pl. 102: March, 1'r. Ac. Phil 1864, p. 69.

Porzana concolor, Newt., p. 114: Scott, Auk, p. 11.

Amanrolimnas concolor, Sharpe, Cat. Birds, xxiii, p. 97.

Hab. Central and South America; Jamaica, resident (Gosse).

156. Porzana Flaviventris.

Minute Crake.

Ortygometra minuta, Giosse, B.J. p. 372, id. Ill. pl. 104.

Crex minuta, Scl. P.Z.S. 1861 , p. 81 :

Porzana minuta, March, Pr. Ac. Phil. 1864

Porzana flaviventris, Scl. et Salv. P.Z.S. 1S6S, \%. 455: Newt. p. 114: Scott, Auk, ix. p. 11: Salvad. Cat. Birds, xxiii. p. 110.

$\mathrm{Hab}$. South Amerivea; occasional in Jamaica (Gosse). 
157. Creciscus jamaicensis,

Ortygometra jamaicensis Gosse, B.J., p. 375.

Porzana jamaicensis, Scl. P.Z.S. 1861, p. 81: March, Pr. Ac. Phil. 1564, p. 69. Scott, Auk, ix. p. 11.

Creciscus jamaicensis, Sharpe, Cat. B. xxiii. p. 135.

$H a b$. North and South America; resident in Jamaica (Gosse).

158. Gallinula galeata. American Waterhen.

Gallinula galeata, Gosse, p. 381: Sclater, P.Z.S., 1861, p. 81 : March, Pr. Ac. Phil. 1864, p. 69: Newt p. 115: Scott, Auk, ix. p. 12: Sharpe, Cat. B. xxiii. p. 177.

Hab.North and South America. A common resident in Jamaica.

159. Fulica Americana. American Coot.

Fulica americana, Gosse, p. 384: Scl. P.Z.S. 1861, p. 81: March, Pr. Ac. Ph. 1864, p. 69: Newt. p. 115: Scott, Auk, ix. p. 12: Sharpe, Cat. B. xxiii. p. 221 ,

$H a b$. North and Central America. A common resident in Jamaica.

160. Porphyriola martinica. American Purple Waterhen.

Porphyrio martinicus, Gosse, p. 377: Scl. P.Z.S. 1861, p. 8. Newt. p. 115

Gallinula martinica, March, Pr. Ac. Phil. 1864, p. 69.

Jopornis martinica, Scott, Auk, ix. p. 12.

Porphyriola martinica, Sharpe, Cat. B. xxiii. p. 189.

$H a b$. Central and South America; not uncommon in Jamaica (Gosse).

\section{Fam. ARAMID $Æ$ (Courlans)}

This well marked form which is generally held to be intermediate between the Cranes and the Rails, contains only one genus in which there are two closely allied species. One of these was formerly found in Janaica as a rather scarce lesident, but is now nearly, if not quite extinct.

161. Aramus giganteus.

Aramus scolopaceus, Gosse, p. 355:

Aramus giganteus, Baird, B.N.A. p. 657: Scl. P.Z.S. 1861, p. S1: Newt. p. 115.

Notherodius holostictus, Cat. J.f.o. 1856, p. 426.

Aramus pictus, Sharpe, Cat. B. xxiii. p. 238.

$H a b$. North and South America: Jamaica formerly abundant, now nearly extinct.

\section{Fam. CHARADRIID无 (Plovers)}

Nine members of the great Family Charadriidæ have been recorded as found in Jamaica, and the list will probably be added to by future observer's. They are mostly winter visitors from the north, but two or three of them occasionally nest in Jamaica.

162. Squatarola helvetica. Grey Plover.

Squatarola helvetica, Gosse p. 333: March, Pr. Ac. Phil. 1864, p. 66: Newt. p. 115: Sharpe, Cat. B. xxiv. p. 182.

Charadrius squatarola, Scott, Auk, ix. p. 14.

$H a b$. Northern hemisphere; an occasional winter visitor to Jamaica.

163. Charadrius dominicus.

American Golden Plover

Charadrius virginiacus, Gosse, p. 333: March, Pr. Ac. Phil. 1864, p. 241:

Charadrius dominicus, Newt. p. 115: Scott, Auk, ix. p. 14: Sharpe, Cat.

B. xxiv. p. 195.

$H a b$. America; an occasional visitor to Jamaica in winter.

164. EGIALITIS WILSONI.

AEgialitis melodus, Ciosse, p. 330.

EEgialitis wilsonius, March, Pr. Ac. Sc. Phil. 1S64, p. 66: Newt. p. 330.

Egialitis meloda, Scott, Auk, ix. p. 15.

Ochthodromus wilsoni, Sharpe, Cat. B. xxiv. p. 214:

$\mathrm{Hab}$. North America; a regular winter visitor to Jamaica.

165.. Egialitis Semipalmata. Semipalmated Shore-plover.

Agialitis semipalmata, Gosse, p. 333: March, Pr. Ac. Sc. Phil. 1864, p. 66:

Newt. p. 115: Scott, Auk, ix. p. 15.

Agialeus semipalmatus, Sharpe, Cat. B. xxiv. p. 250.

$\mathrm{Hab}$. North America; resident in Jamaica, and breeding there. 
166. Aigralitis VOCHFER.

Killdeer Plover.

Egialitis vocifera, Gosse, 1). 330: Mareh, P1. ('c. Phil. 1864, p. 66: Newt. p. 115: Scott, Auk. ix. p. 15:

Oxyechus vociferus, Sharpe, Cat. 13. xxiv. 1). 212.

Hab. North America; resident in Jamaica and breeding there.

167. Strepsilas interirlis.

'Tiuristone.

Strepsilas interpres, Gosse, p. 3333): March, Pr. Ac. I'hil. 1864, 1. (ifi: Newt. p. 118.

Arenaria interpres, Scott, Auk. ix. p 115: Sharpe, (at. B. xxir. p. 91. Hab. Cosmopolitan: found in flocks on the shores of Jamaica in winter.

168. Recurviostira americana.

Anerican Avocet.

Recurviostra americana, Gosse, B J., p. 389, Newt, p. 119: March, Pr. Ac* Sc.Phil. 1S64, p. 67: Scott, Auk, ix. p. 12: Sharpe, (at. B. xxiv. p. 330 $H a b$. North America; an occasional visitor to Jamaica in winter.

169. Himantopus nigricolalis. Black-necked Stilt.

Himantopus nigricollis, (iosse, B. J. p. 186: id. Ill. pl. 108: March, Pr. Ac. Phil. 1S64, p. 67: Newt. List, p. 113.

Himantopus moricanus, Scott, Auk. ix. p. 12: Sharpe, Cat. B. xxiv. p. 320.

II ab. North Americal; a not uneommon visitor to Jamaiea in winter.

\section{Fam. SCOLOPACDDA (Suipes)}

The member's of the Snipe Family, like the Plovers, are not in any case permanent residents in Jamaica, but more or less occasional winter visitors. At present about 17 of them have been registered in Jamaica, but the list will probably be augmented when fresh observers take up the work of looking after the birds.

170. Bartramia longicauda. Bartram's Sandpiper.

Actiturus bartramius, March, Pr. Ac. Sc. Phil. 1S64, p. 67:

Bartramia longicauda, Scott, Auk, ix. p. 14: Sharpe, Cat. B. xxiv. p. 509.

$H a b$. N. Amcrica; a scar'ce straggler in Jamaica.

171 TRINGOIdes MaCUlarius.

Spotted Sandpiper.

Actitis macularius, Gosse, B.J. p. 349: Scott, Auk, ix. p. 14.

Tringoides macularius, Sel. P.Z.S. 1861, p. 80: Newt. List, p. 113.

$H a b . \mathrm{N}$. America, visiting Jamaica in winter and sometimes remaining to nest.

172. Totanus solitarius.

Totanus chloropygius, Gosse, B. J., p. 350.

Rhyacophilus solitarins, Scl. P.Z.S. 1861, p. 80: March, Pr. Ac. Sc. Phil. 186t, p. 67: Newt. p. 115.

Totanus solitarius, Scott, Auk, ix. p. 14.

Helodromas solitarius, Sharpe, Cat. B. xxiv. p. 444.

Hab. North America; a common winter visitor to Janaica.

173. Totanus hiavipes.

Yellow-legged Sandpiper.

'otanus flavipes Ciosse, p. 351: Newt. p. 116: Scott, Auk, ix. Sharpe, (at. B. xxxy. p. 431.

Ciambelta flaripes, March, Pr. Ac. Sc. Phil. 186t, p. 68:

Hab. North America; a regular winter visitor to Jamaica.

174. 'Totanus melanoleueus'. Tell-tale Sandpiper.

Totanzes melunoleucus, (iosse, p. 352: Newt. p. 116: Seott, Auk. is p. 14: Sharpe, Cat. B. xxviii. p. 426.

Gambetta melanoleuca, Scl. P.Z.S. 1861, p. 80 : March, Pr. Ac. Śc. Phil. 1S64, p. 68.

$H a b$. North America; a regular winter visitor to Jamaica.

175. Symphemia SEm!Plimata. Semipalmated Sandpiper.

Catoptrophorus semipalmatus, Gosse; p. 35.t.

Symphemia semipalmata, March, Pr. Ac. Sc. Phil. 1S64, p. (it, Newt. p. 116: Scott, Auk, ix. p. 14: Sharper: Cat. B. xxiv. p. 405.

$H a b$. N. America ; a casual winter visitor to Jamaica.

176. NuMENiUS LONGIROSTRIS.

Long-billed Curlew.

Numenius longirostris, Gosse, p. 318: March, Pr. Ac. Sc. Phil. 186t, " 68:

Newt. p. 116: Scott. Auk, ix. p 14: Sharpe, Cat. B. xxiv. p. 352.

Hab. North America: a casual visitor to Jamaica. 
177. Micropalama himantopus.

Stilt Sandpiper.

Micropalama himantopus, March, Pr. Ac. Sc. Phil. 186t, p. 67: Newt. p. 161:

Scott, Auk. ix. p. 13: Sharpe, Cat. B. xxiv. p. 401.

Hab. North America; a casual visitor to Jamaica.

178. Calidris arenaria.

Sanderling.

Calidris arenaria, Gosse, p. 354, March, Pr. Ac. Phil. 1864, 1. 67: Newt. 1). 116: Scott, Auk, ix. p. 13: Sharpe, Cat. B. xxiv. p. 526.

Hab. North America; a common winter visitor to Jamaica.

179. Ereunetes pusiluus.

Ereunetes pusillus, Cassin, Pr. Ac. Sc. Phil. 1860, p. 195: Newt. p. 116:

Scott, Auk, ix. p. 13; Sharpe, Cat. B. xxiv. p. 514.

Pelidna pusilla, Gosse, B.J. 348 (?)

$H a b$. North America; an occasional winter visitor to Jamaica.

180. Tringa minutilla.

Least Stint.

Tringa wilsoni, Scl. P.Z.S. 1861, p. S0.

Tringa minutilla, Newt. p. 116: Scott, Auk, ix. p. 13:

Actodromas minutilla, March, Pr. Ac. Phil. 1864, p. 67.

Limonites minutilla, Sharpe, Cat. B. xxiv. p. 548.

Hab. North America; a regular, but not very common winter visitor to Jamaica.

181. Tringa FUSCICOLLIS.

Tringa bonapartii, Scl. P.Z.S. 1861, p. S0:

Bonapartes' Sandpiper.

Tringa fuscicollis, Newt. List, p. 116: Albrect, J.f. Orn. 1862 p. 205: Scott, Auk, ix. p. 13.

Heteropygia fuscicollis, Sharpe, Cat. B. xxiv. p. 574.

$H a b$. North America; Jamaica occasionally, in winter.

182. TRINGa maCULATA.

Pectoral Sandpiper,

Tringa maculata, Newt. p. 116: Scott, Auk, ix. p. 13.

Heteropygia maculata, Sharpe, Cat. B. xxiv. p. 562.

Hab. North America; an occasional visitor to Jamaica.

183. Tringa Canutus.

Knot.

Tringa canutus, Gosse, p. 201: March, Pr. Ac. Sc. Phil. ix, 1864, p 67: Newt. p. 116: Scott, Auk, ix. p. 13: Sharpe, Cat. B. xxiv. p. 593.

$H a b$. North America; an occasional visitor to Jamaica, in winter.

184. Macrorhamphus griseus. Brown Snipe.

Macrohamphus griseus, Cass \& Baird, B.N.A., p. 712: Newt. p. 116: Scott, Auk, ix. p. 13: Sharpe, Cat. B. xxiv. p. 394.

$H a b$. North America; an occasional visitor to Jamaica.

185. Gallinago delicata.

Wilson's Snipe.

Gallinago wilsoni, Gosse, p. 353; Newt. 116: March, Pr. Ac. Ph. 1864 p. 67.

Gallinago delicata, Scott, Auk, ix. p. 12: Sharpe, Cat B. xxiv. p. 642.

$H a b$. North America; a winter visitor to Jamaica.

186. Philohela minor.

American Woodcock,

Rusticola minor, Gosse, p. 354, March Pr. Ac. Sc. Phil. 1864, p. 68.

Scolopax minor, Newt. p. 316.

Philohela minor, Scott, Auk, ix. p. 12, Sharpe, Cat. Birds, xxiv. p. 679:

$H a b$. North America; an occasional visitor to Jamaica in winter.

Fam. LARIDAE. (Gulls).

Only five species of gulls and Terns have as yet been recorded from the shores of Jamaica but about twenty have been met with in the Antilles, so that there are propably many still to be added to this part of the Jamaican List. The American Check-list contains the names of more than forty Gulls and Terns.

187. LARUS ATricilla.

Xema atricilla, Gosse, p. 437.

Larus atricilla, Newt. p. 117: Scott, Auk, viii. p. 362: Saund. Cat. B. xxv. p. 194.

Hab. North America : met with on the south coast of Jamaica.

188. Sterna maxima.

Thalasseus cayanus, Gosse, p. 431.

Sterna regia, Scl. P.Z.S. 1861, p. 82.

Sterna maxima, Scott, Auk, viii. p. 362: Saund. Cat. Birds, xxv. p. S0.

$\mathrm{Hab}$. North America. Met with on the south coast of Jamaica. 
1S9. Sterna anthllarum.

Sterna argentea, Gosse, B. J.p. 437 (Hill).

Sternu ontillarum, Newt. p. 117: Saunders, P./.S. 1876, p. 661: Scott, Auk, viii. p. 362.: S:mund, ('at. Birds xxiv. p. 122.

Hub. N. Americit: south co:ast of Jamaica.

190. StThra Fudiginosa.

Mydrochelidon fuliginosa, Gosse, p. 4:3:3.

Girest Sooty Tern.

Sterna fuliginosa, Newt. List, p. 117: Seott, Auk, ix. p. 361: Saund. Cat. Birds xxy. p. 106.

Hab. North America: south coast of Jannaica.

191. II Ýdrocitelidon Nigra. Black 'Tern.

Hydrochelidon nigra, (iosse, p. 437: Newt. List, p. 117: Saund. Cat. Birds, $\mathrm{xxv}$. p. 17.

Hydrochelidon nigra surinamensis, Scott, Auk, viii. p. 360.

Hab. North America: south coast of Jamaica.

\section{Fam PROCELILARIID A (Petrels).}

The great marine Family of Petrels is represented in the Jamaican Avifauna by one species only-an QEotrelata which, like some other members of that genus selects as its breeding-place the highest tops of the mountains-Like other terrestrial birds in Jamaica this Petrel has been recently subjected to the ravages of the Mongoose, and it seems rather doubtful whether any of its representatives are still existing.

192. (Fíreiata Jamaicensis. 'Blue Mountain Duck' Gosse, B.J. p. 437.

Procellaria jamaicensis, Bancroft, Zool. Journ. v. p. 81.

Es'relata jamaicensis, Newt. List, p. 117: Grant, Cat. Birds, xxv. p. 403: Godman, Mon. of Petrels, p. 189, pl. 50.

Estrelata, caribbcea Scott, Auk, viii, p. 355.

Hah. Jamaica, breeding on the mountains, supposed to be now extinct.

\section{PODICIPEDIDA (Grebes).}

Two species of the aquatic Family of Grebes belong to the Jamaican List. One of them is a permanent resident, the other an occasional visitor. Six Grebes find a place in the North American Avifauna, so that it is possible that an addlition may be made to the present number in Jamaica.

19.. Pudicers Dominicus. White-winged Grebe.

Podiceps dominicus, Gosse, B. J., p. 440, id. Ill. pl. 120: March, Pr. Ac. Phil. 1864, p. 70: Newt. p. 117: Grant, Cat. Birds, xxv. p. 520

Colymbus dominicensis, Scott, Auk, viii. p. 354

Hab. North America; resident in Jamaica.

191. Podilymiós podiceps.

Podiceps carolinensis, Gosse, B.J. p. 438.

Poditymbus podiceps, Scl. P Z.S. 1861, p. 82: March, Pr. Ac. Sc. Phil. 186t, p 70: Newt. p. 117: Scott, Auk, viii. p. 353: Grant, Cat. Birds, xxvii. p. 55.3.

Hab. N. America: occasionally met with in Jamaica.

\section{CONCLUDING REMARKS.}

As shown by the List, the Avifauna of Jamaica, as at present known to us, contains about 200 species, though, no doubt, many more "accidental visitor's' remain to be added to it 'These species fall into three principal categnies-

$\begin{array}{ccccc}\text { i. Constant Residents } & \ldots & \ldots & \ldots & 99 \\ \text { ii. Winter Visitors } & \ldots & \ldots & \ldots & 52 \\ \text { iii. Occasional Visitors } & \ldots & \ldots & & 4.3 \\ \end{array}$

I will make a few remarks on each of these divisions

The 99 'Constant Residents' are divisible into two sections (1) those that, so tar as we know at present, do not occur elsewhere, but are absolutely confined to Jamaica, and (2) those that have a more or less wide range outside the Island. The former are 42 in number, the latter are 57. 
The following is a list of the 42 species which are believed to be absolutely peculiar to Jamaica and may be denominated "autocthonous."

AUTOCTHONOUS BIRDS OF JAMAICA.

No. in Gen.

List.

No. in Gen.

-1
2
3
5
10
11
14
15
17
18
19
20
22
34
36
45
46
48
52
54
55

22 Pitangus jamaicensis.

List.

1 Corrus jamaicensis

2 Quiscalus crassirostris

*3 Nesopsar nigerrimus.

4 Icterus leucopteryx.

5 Pyrrhulagia l'uficollis.

6 - anoxantha.

*7 Pyrrhuphonia jamaica.

S Spindalis nigricephala.

*9 Glossiptila ruficollis.

10 Certhiola flaveola.

11 Turdus jamaicensis.

12 - aurantius.

1.) Mimus hilli.

antius. 20

14 Dendroea pharetra.

15 - eoa.

16 Vireo modestus.

*17 Laletes osburni.

18 Myiadectes solitarius

19 Petrochelidon euchrysea.

20 Elainea fallax.

21 Myiopagis cotta.

23 Blacicus pallidus
24 Myiarchus stolidus.
25 barbirostris.
26 Platypsaris niger.
*27 Hylonax validus.
28 Lampornis mango.
*29 Aithurus polytmus.
*30 Siphonorhis americanus.
*31 Hyetornis pluvialis
32 Saurothela vetula
33 Centurus radiolatus.
34 Todus viridis.
35 Chrysotis collaria.
36 - agilis.
37 Conurus nanus.
38 Ara gossii.
39 Asio grammicus.
40 Leptoptila jamaicensis.
41 Geotrygon clistata.
42 CEstrelata jamaicensis.




\title{
PUBLICATIONS
}

\author{
To be obtained at the Institute.
}

Root Food Growth in Jamaica. By Rev. J. Cork.

Some Objects of Productive Industry: Native and other Fibre Plants. By D. Morris.

Outline of a Lecture on Vegetable Chemistry. By J. J. Bowrey a

The Cultivation of the Orange in Jamaica. By Dr. James Neish

The Vine and its Culture By Rev. Wm. Griffith ․ .

The Cultivation of the Ramie. By Hon J C. Philulppo . .
On a New Beverage Substance. The Kola Nut. By Dr. James Neist

The Advantages to result from Railway Extension. By Hon. W. B. Espeut

$\left.\begin{array}{l}\text { On the Geology of Jamaica } \\ \text { On Mining in Jamaica. }\end{array}\right\}$ By Rev. H. Scothand

The Mineral Springs of Jamaica. By Hon. J. C. Puillippo

A Provisional list of the Fishes of Jamaica. By T. D. A. Cockereru, F.Z.S., F.E.S.

Institute of Jamaica Lectures: Agriculture.

List of the Decapod Crustacea of Jamaica. By MARY J. RAtribun $\quad$.

The Economic Geology of Jamaica. By F. C. Nicholas

The Rainfall Atlas of Jamaica. By Maxwell HaLl, M.A. ..

The Meteorology of Jamaica. By Maxwell Hald, M.A.

Systematic Catalogue of the Land and Fresh-water Shells of Jamaica. By Henry Vendryes

The Mosquitoes or Culicidæ of Jamaica. By F. V. Theobald, M.A., and M Grabham, M.A., M.B. [illustrated]

Post Free.

$18816 d$.

$18846 d$.

$18846 d$.

$18846 d$.

$18846 d$.

$18846 d$.

$18876 d$.

$18876 d$.

$18896 d$.

$18916 d$.

1892 Grulis

$18932 / 6$

$18971 s$.

$18992 d$.

$1892 \quad 2 / 6$

$19046 d$.

$18993 d$.

$19056 d$.

Revised List of the Birds of Jamaica (based on Newton's List). By P. L. Sclater, Dr. Sc., F.R.S

1910

The Journal of the Institute of Jamaisa [illustrated]-

Vol. I., Pts. i., ii., iii., iv., [others out of print] per part

Tol. II., Pts., ii and v. (Pts, i. and iii. out of print)

Vol. II., Pt. iv. [Special "Aboriginal Indian Remains" Number]

Vol. II. Pt. vi.

Vol. II., bound

Bibliotheca Jamaicensis: Some account of the principal works on Jamaica in the Library of the Institute By Frank Cundali F.S.A.

Bibliographia Jamaicensis: A list of Jamaica books and pamphlets, magazine articles, newspapers and maps, most of which are in the

Library of the Institute of Jamaica, By Frank Cundali

Supplement to Bibliographia Jamaicensis. By Frank Cundall ..

Bibliography of the West Indies. By Frank Cundalu

Classified List of Book; Agriculture

Catalogue of Books in the Library of the Institute

List of Books on Jamaica in the Library of the Institute, Excerpted from the Catalogue

Classified List of Books [Except West Indian] added to the Library since 1895

Studies in Jamaica History. By Frank Cundall. Illustrated by Mrs. LiONEL LeF

Biographical Annals of Jamaica. By Frank Cundali [Illustrated]

Jamaica in 1905: A Handbook of Information for intending Settlers and Visitors. [With Illustrations and Map] By Frank Cundali, [out of print]

Political and Social Disturbances in the West Indies: A Brief Account and Bibliography. By Frank Cundald

A brief Guicle to an Exhibition of Maps of the Sixteenth Century Illustrative of the Discovery of America. By Frank Cundall [Illustrated]

Lady Nugent's Journal. Jamaica One Hundred Years Ago. Edited by Frank Cundall. [With Illustration
Place-Names. By Frank Cundall

Jamaica Place-Names. By Frank Cundall by Izet Anderson, M.D.
Jamaica Proverbs. Collected and arranged by

1905 

Gaylord Bros.

Makers

Syracuse, N. Y.

PAT. JAK, 21, 1908 
